\title{
Allen.
}

Village life in Japan. 

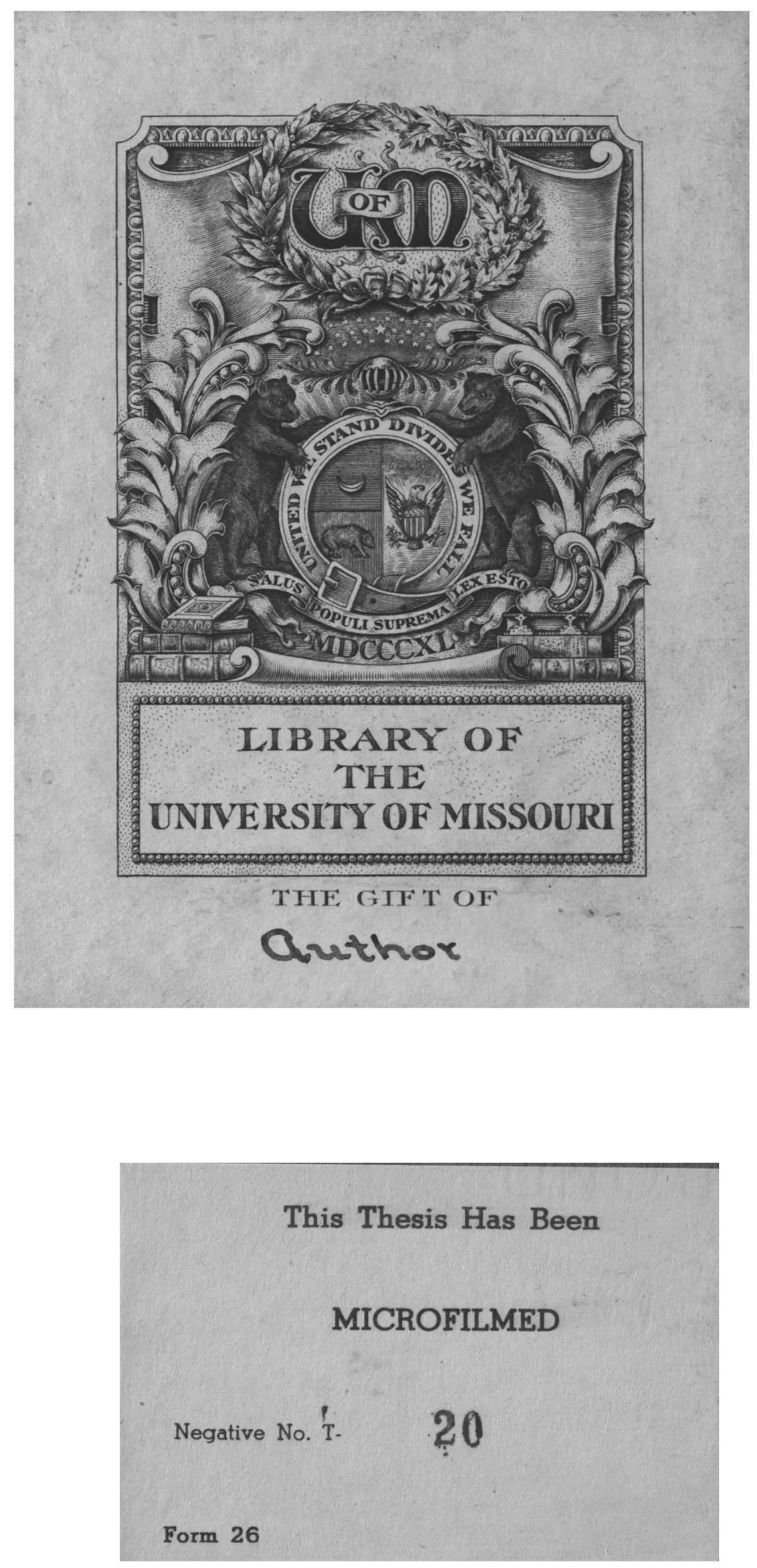






VILIAGE IIFE IN JAPAN

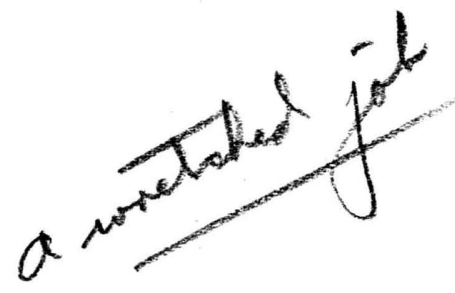

by

ELMER JACKSON ALIEN, A.B.

SUBMITTED IN PARTIAL FULFIIIINENT OF THE

REGUIREMENTS FOR THE DEGREE, $O$

MASTER OF ARTS

in the

GRADUATE DEPARTNENT

(COILEGE OF ARTS AND SCIENCES)

of the

UNIVERSITY OF MISSOURI

1909.

Received

JUN 141909

UNIV. OF MO. 

CONTENTS.

Page.

Introduction

Resumé of History of Japan and Present Political Organization.

The Origin, Growth and Politicel Organiration of Villages in Olden Times.

Present Political Organization

Executive, Legislative, Judicial, Sanitation, suffrage.

Physical Features

General Aspect of Villages, Shops, Houses, Gardens.

Regulations

The People

Characteristios, Dress, Customs, Politeness, Food.

The Family

Afarriage, The Family, The Position of Woman, Domestic Servants.

Morality

Standards of Virtue, Association of the Sexes, Irudity.

Religion

Shinto, Budahism, Religious Life of Village,

Household Religion, Superstitions. 

Hiatorical Sketch, Comparison of American and Japanese Schools, The Elementary School, Management, Teachers.

Village Finances

Sources of Income, Expenditures.

Industries

Agriculture

Soil, Fertilizers, Methods of Farming, Size of Holdings and Fields, Crops, Isind Ownership, Secondary Fork for Farmers, Farm Laborer, Rent, Living Expenses.

Fishing

Extent, Value of Boats and Nets, Value of

Iakes, Marine Products, Fish Culture.

Salt Refining

Methods Used, Amount Produced and Number of People so Fngaged.

Tea Raising

History, Tea Drinking, Culture.

Sericulture

History, Present Fitent, Methods.

Manufacturing

Home Work, Intercourae with Foreign

\section{Trader 8.}

Neights and Measures. 

IIST OF ILLUSTRATIONS.

Page

1. A street in Tokuyama during a Festival Time 16

2. Japanese Gardens . 21

3. Buddhist Grave Yard 35

4. Mother and Child 43

5. Inside of a Buddhist Temple 65

6. Shinto Shrines 65

7. Paper Fish flown on the Boys' Festivel Day 68

8. An Elementary School 75

9. School Children 82

10. Coountry Hidne 85

11. Peasants : 86

12. Terraced Fields 87

13. Applying Night Soil 87

14. Preparing Upland for Wheat 89

15. In Paddy Fields 89

16. Plowing 90

17. Transplanting Pice 91

18. Cutting Rice 91

19. Threshing Rice 92

20. Drying Grain 92

21. Going to Market 93

22. Cleaning Grain 93 



\section{VILIAGE LIFE IN JAPAN}

INTRODUCIION.

The content and environment of Japanese life are so totally different from those of American life that it may not be amiss if we consider first some of the difficulties to be met with in any sound and unbiasdd discussion of the life of the common people. It is unsafe to take anything for granted or to draw general conclusions. One therefore in writing upon any phase of Japanese Iife must either depend upon his own observations, and these must extend over many years to be of any value; or be able to cull from the great mass of written material the few kernels of truth that it contains. One soon learns, however, how very difficult, in fact how nearly impossible, it is for a westerner to gain first-hand information of any worth or accuracy in the study of social conditions in Japan; and likewise how few really valuable things have been written along the lines which are here undertaken. I have consulted practically everything available in English bearing in any way upon the different phases of the life of the common people in the smaller communities, and have endeavored to choose from this the things that give a notion of what that Iife really is; and have arawn from my own experience of a residence of three years in Japan. The more, however, that I think of the Japanese as they are the more impossible it seems to present a picture that will give any adequate conception of the reality. And yet the question of the village life "is a most important one, for it is in the villages that 

survive the most numerous traces of the past. In the towns the old landmarks are being rapidly obliterated". 1

It is well to remember that Japan's history dates back, accorilng to their own chronology, to $660 \mathrm{B.C}$, and that for all this long time up to 1853 it was isolated from practically all the world. This was especially true during the 250 years just preceeding the "opening", for during all this period the only communication Japan had with the outside world was thru the occasional visits of a few Dutch trading vessels. Nor must we forget that Japan, Instead of being a large continent of broad acres and fertile soil, 18 made up of a large number of islands-some six hundred in number-and these are largely occupied by mountains so that only a small portion is tillable and even this portion is not naturally fertile. Nor yet must we leave out of consideration the density of the population. The average is about three hundred to the square mile, but in the western part of the main island there are 2945 to the square mile.

A brief survey of the history of the country must precede any effort to understand the present. Without considering the question of the reliability of the early Japanese mythology, suffice it to say that the people probably came from China or Korea sometime about the fifth or sixth century before the Christion era and settled first in the island of Kyushu and

1. Transactions of the Asiatic Society of Japan, vol. XXXIII pt. 2, p. 133 . 

that their government was of the tribal order. The chieftain who lead the expedition which came over a little later from Kyushu to the mainland of Hondo and established a government by conquest, before long came to bear the title of Bmperor. He was all along simply the leader of the strongest tribe and maintained his supremacy by force of arms. As the country became more organired this supremacy became more real and permanent, and the people early developed their mythology concerning the divine origin of their ruler and thus he came to be held as sacred and inviolable. Along with, and perhaps in a great measure the cauge of this notion of imperial divinity, "there arose families of nobility who shared and dictated the power and developed the two official castes of the civilian and the military officials, widening the distance botween the sovereign and his people and rendering him more inacessable to his subjects". Ag the porer of the emperor became stronger the government was gradually changed from simple feudalisin to a centralized monarchy. Beginning with about $600 \mathrm{~A} . \mathrm{D}$., which by the way may be taken as the beginning of authentic history, several great military families, one after the other, for about seven hundred years were the real rulers of the country under the title of "Shogun". which is merely the word for general. In this way such families as Fujiwara, Taira, Minamoto, Ashikaga, and Tokugawa held the real power of the throne and tho the emperor was all the time the nominal ruler, yet it point of fact he was merely a puppet in the hands of the shogun.

1. The Mikado's Empire p 101. W. E. Griffis. 

Up to the beginning of the Tokugawe Shogunate, 1603 , the country was in a state of war almost continually; the vatious tribal chieftains, about 300 in number, warring with each other. Fach was almost wholly independent, religiously and administratively, of the rest. These Daimyo, as they were called, were the lords of the country, the "kings" spoken of in many of the early writings on Japan. They were the richest and by far the most important aristocracy in the land. They owned land assessed at from 10,000 bales of rice per annum to more than a million bales. ${ }^{1}$ But with the inauguration of the Tokugawa family in the place of power in 1603, with that noted general Ieyasu powerful enough to put down all opposition, cane an era of peace which lasted down to the bloodless revolution which restored, In 1868, the real governing power into the hands of the emperor and established the present "ers of enlightenment" or Meiji government. During this period of peace the feudal system was thoroly worked out. Previously, as has been remarked above, each clan had its own religion but now, that one clan had become strong enough, it imposed its own cult upon all the others, and thus arose the national cult with the Emperor at the head. We may say that this marks the end of the first period in Japanese social evolution. Even during the Tokugawa period the daimyo were largely supreme in their own domains, the shogun exacting only $\dot{a}$ stipulated tax, quota of troops and certain observances, tho cases are not unknown where daimyo were punished, even to the I0ss of their estates, for oppression and cruelty.

1. The value of these bales has been estimated at about $\$ 5.00$ each.

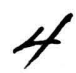



The daimro had in turn their vassals, and attached to all of these, shogun. daimyo, and lesser landed proprietors were the men of war, the samura1, in all perhaps about $2,000,000$. "The training, the occuption, the code of honor, the whole mental atmosphere of the samural exhtbited a striking similarity to those of our own (Inglish) nobility and gentry of the Midele Ages. With them, as with us, obedience, uncuestioning and enthusiastic, was yielded to fendel superiors; to monarchs, ruling by right nivine-obedience even to death. With them, as with us, it was birth ond breeding that counted, not money"! In short they were men trained in the spirit of Bushido, thar which nothing but the spirit of the christ is more noble.

As to the condition of the common people $\mathrm{Mr}$. Hearn claims that there is little doubt that the bulk of them were in a condition of servitude and that they remained till modern times in a conation analagous to serfom. The present count Itagaki confirms this by saying-"The mass of the people lat the coming of Commodore Perryl had been reduced to a state of actual slavery as the result of the long established tyranny of feudaliom. "2 The bulk of the people were dielded into three classes: farmers, artisans and merchants. These were all classed together as "heimin", common folk, and were lower than the samural to whom they were in a sense subject, in so much that a samurai might kill a heimin who showed him aisrespect and in all probability never be questioned by injone on account of the deod.

Hopelessly below all these were a fow people, known as "Ita", a class whom we shall call the pariah people. They lived

1. Things Japanese ṕ. 415. B. H. Chamberlain.

2. Japan Times. 

apart from other people and did such work as was considered beneath a man to do. They may have been the descendants of the aboriginese found there, tho of this we cannot be certain.

This then was the state of affatrs when Commodore Perry made his visit to the Land of the Rising Sun and by his very audacity and by the force of the argument that the presence of his battleshlp hade, sacceoded, In 1354, in arranging a treaty with the Mikado, or rather with the Shogun. From that time till 1868, when the new regime emerged, were stirring times Indeed, but space forbids me to take up these mattors further. "The jear 1889 was a rod-letter year in the calendar of Japan's political progreas. On February 11, was promulgated that famous document (the Constitution) which took Japan forever out of the ranks of Oriental despotiams and placed her among constitutional monarchies; and on April 1, the law of local self-government for city, town, and $\nabla 11$ lage went into effect." I It is, horever, very significant to note what, in the minds of the Japanese. led to all these changes and the progress generally. It cannot perhaps be better put than in the words of one of the leading noblemen at present. "Iooking back along the trail over which the nation has travelled in the course of its developing career and studying the causes that have brought about the accomplishment of the great work of 'Regeneration'. It is plain that all in all we owed it to the glorious virtues of our Emperor, assisted by the people who have rendered their services in observance of the Imperial precepts handed down from past ages". 2

1. A Handbook of Modern Japan p. 120. E. F. Clement. 2. Japan times. Itagaki, Circular to Press. 

The country, exclusive of Hokkaido and Formosa, is divided into forty-six prefectures. The prefectures, or "ken", are divided into "gun" and civic corporations, lcities, towns and villages). "A governor apnointed in each prefecture represents the central government administratively, while a local assembly represents the rights and interests of the pecple. $A$ an is a miniature prefecture and possesses an executive chief and an assembly. Cities, towns, and villages are bona-fide self-governing entities". ${ }^{I}$ of these municipal organizations there are anproximately 60 oities,, 1,100 towns, and 13,000 villages-- these latter being communities of not more than 3000 inhabitants. The cities and town contain about $25 \%$ of the population, and of the remaining $75 \%$ it is safe to say that at least $70 \%$ Iive in villages. It is fitting then that the Japanese people be studied from the standpoint of the village community.

Here it may be remarked that the Japanese viliage of old had many points in common with the "village communities" of India and Ingland. Among the roints oommon to both may be mentioned- the common use of grass of waste land; the division of the land into small strips or pieces, and each man holding small pieces instead of one large one, and these pieces separated from each other; submission to a village headman; and the fact that each house was ruled over by a pater-familias. As a matter of fact many, if not all of these things may be found in existence in villages in Japan to-day.

1. Japan Year Book 1905 p. 62 . 

EE ORIGIN, GROWTH AND POIITICAI ORGANIZATION OF VIIJAGES IN OLDEN TIMES.

The general aspect of villages to-day bears evidence to their origin which in most cases would seem to have been by the settlement of a single family at first and a gradual building up of the community. There is much eridence to show that in many, if not in nost, cases the community was made up of families related by blood ties, and strangess if admitted were generally adopted into a family. In all cases we may say that all the people were one in religion, all worshiping at the same parishtemple. The delt there worshiped as tutelar god was called "Ufigami". (the god of the uji which term originally signified the patriarchal family or gens. "Some obscurity still attaches to the question of the original relation of the uflgami to the community. Hirata declares the god of the Ufi to have been the common ancestor of the clan-family."I "Nost probably the god of th the Ufi was first worshiped by the people of the district rather as the spirtt of a former ruler, or patron-god of the ruling family, than as the spirit of a common ancestor"

This first family around which the community grew up usually became not only the leading family in wealth and social position but in reality the patriarch of the village. "Justas the Emperor sat on his throne by virtue of his descent, as the Shogun belonged to the family of Tokugawa, and the Daimyo in every province or domain ruled by hereditary right, so in every village there was a ruling family, the head of which was also the hereditary headman of the community. The headman of the

1. Japan- An Interpretation p. 93. Lafcadio Hearn. 

village occupied to the daimyo of the province or domain the same position that the daimyo occupied to the Shogun. "I The headman. nanushi or shoya. was in theory unpaid yet he had certain perquisities in the form of offerings of the first fruits,help in his labors by all villagers etc. He was assisted in his work of governing by a council of "Kumi-gashira" or heads of kumi or companies. The families constituting the village were organized into groups of five families each, in exceptional cases the number sometimes went as high as ten tho not often, for the common name by which these groups were known was "gonin-gumi", a part of which signifies five. The origin of this system of organization is not definitely known, tho it is probably copied after the Chinese system. Its purpose was doubtless at first to facilitate the furnishing of soldiers. It served also as an aid to government and as a protection to the people themselves, for all members of the kumi were bound to stand by each other in all cases. The deimyo received his fief from the emperor and he in turn granted land to his vassals and also to the villages in his domain. This land granted to the villages consisted of temple land, timber land and land reclaimed from swamps and river bottoms. It was held as the common property of the village and there were regulations concerning its use,e.g. there were certain days on which wood might be taken from the forest, or the pine needles and such wood as was on the ground be gathered. somewhat after the custom in German villages of gathering leaves on certain days. As the chiefs had to furnish troops to their lords in return for the land and protection granted them,

1. Transactions of the Asiatic Society of Japan v.XXXIII pt. 2 p. 133 . 

so the villages had to do the same, and the organization of the families into companies or kumi regulated and facilitated both the payment of taxes and the furnishing of troops.

There were generally no written laws but in every village there would be some public place where communications from the daimyo and from the local officials were posted that all might see. It was the duty of the nanushi also upon receiving any important communication from the diimye to call the people together and explain the matter to them and then to see that it was carried out. This would be done largely thru the knmi-gashira

\section{'QESENT POIITICAL ORGAIIZATION.}

Executive As has been said above, the village, in its political organization, is a self-eoverning entity. It has its executive, called soncho, who is elected by the people $e^{1}$ and who is their representative in dealing with higher authorities, the governor of the prefecture and representatives of the national government. At the same time he is the representative of the national and prefectural goverrments in that he is expected to see that all measures coming from those sources are observed by the people. In his capacity as representative of the people of the village his duties may be summed un undex the following heads:-

a. To prepare measures to be aiscussed in the village Assembly and to execute what the $\mathrm{s}$ ssembly decides uron. He has a right of veto over the acts of the Assembly.

b. The administration of public property.

c. The supervision of income and outlay.

1. Many vriters cla im that the soncho and his deputies are chosen by the village assemblj. 

d. The protection of the rights of the community.

e. The administration of the tax system.

f. The supervision and discipline of officials and employees.

As representative of the national and prefectural governments, his functions are:-

a. To marage the imperial judicial power and the local administrative folice power.

b. To look after the sea-coast office business which takes care of shipwrects.

c. To see to the administration of general home affairs"such as the census, education, industry and sanitation".

Two or more villages ray by mutual. Egreement and with the consent of higher uthorities form a union for the administration of their common affairs.

Iegiolative. The Assembly is the most important organ in tre governing system of the village. The number of members is from eight to thirty and their term of office is six years, half of them heing elected every three years. A small village may substitute for the Assembly "a general meeting of all citizens having suffrage".

Judicial. The village has no judiciary. The lowest form of court, the local court, presided over by one juage, is rela in the towns and Ell cases demanding trial must be taken there. There are, however, in every village cne or more policemen, and these have the authority to sit in judgement upon slight offenses and to hold preliminary examinations in more serious cases. There are rorice regulations that are very strict in many ways and it is the duty of the police to see that the

$$
\text { IR. }
$$



are carried out. "Theoretically, the police power belongs entirels th the Imperial Government and local self-governing bodies exercise police powers, not of their own right, but simply because it is delegated by laws passed by the Diet and by Imperial ordinances." 1

"The Japanese policeman is one of the most interesting 'characters' of his nation. He is the successor of the samural, who, in the old regime, took upon themselves the duty of enforcing fustioe. He possesses all the pomp and dignity of his knightly predecessor; and he, too, carries a sword. All the people from children up to grandfather, stand in complete awe of him. And well may they be afraid,-for in his dealings, at least with the common people, he manifests no gentleness, but by his dictatorial manners compels the utmost respect for himself and the law. He seldom has to use force in making an arrest, unless in the cases of the professional oriminals; and he does not usually find it necessary to use hand cuffs, as a strong cord will serve his purpose on ordinary occasions. He is more easily to be found, when wanted, than the proverbial Amerioan policeman (for one reason he is much more numerous than in Amerioa). He is poorly paid, but richly faithful, and in every sense of the word upholds the dignity of the law. H1s figure clad in white or blue uniform, respectively, for five and seven months of the year, is familiar and welcome to foreighers, because he is invariably kind and courteous." 2

1. Locar Finances in Japan p. 16. Bunshiro Hattori.

2. A handbook of Modern Japan. p.162. 



$$
\text { "The criminal code }{ }_{\wedge} \text { specifies three kinds of crime:- }
$$

(1) Crimes against the state or the Imperial Fumily, and in violation of the public credit, policy, peace, health etc.

(2) Crimes against persons or property, and (3) pollce offences. There is furthermore $a$ subdivision of $(1)$ and (2) into major and minor crimes". The punishmente for police offences are detention for from one to ten days without hard labor, and flnes varying from $21 / 2 \phi$ to $\$ 1.00$. The court which has charge of police offences is presided over by one juge de paix. "Crimes of whatever sort, except police offences, are as a rule subject to preliminary examination before trial". 2 This, however, may be delayed and bail allowed or not at the discretion of the judge, so that accused persons may be dotained for a considerable period. No counsel is allowed at this preitimary examination which is searet. As a result of this examination the prisoner maj either be released or held over for trial before the proper court. "A trial in Japan, as in France, is of the inquisitorial type and is conducted by the judge (or judges) alone. All questions by the counsel: must be put thru him. The government is represented by a public procurator, who seems to combine in one person the duties of inspector, grand jury, and prosecuting attorney. Hearsay evidence is admitted, and circumstantial evidence has no small influence." 3

Sanitation. Reference was made above to the fact that the policeman, among other duties, saw that sanitary measures were ob-

1. Things Japanese. P.280

2. ThIngs Japanese. P.28I

3. A Handbook of Modern Japan. P.163 

served by the people. There is usually in the village, also a special committee whose duty it is to see that thing are kept as they ought to be and to report to the police any delinquiney in that regard. While all villages have only open drains, yet it is fair to say that, with for exceptions, they are wonderfully clean. This fact is accounted for in a measure by the fact that any and every organic substance is utilized as fertilizer for the fields and so there is no such thing as decaying animal or vegetable matter lying around. All refuse from water closets, manure of all kinds etc. is used in the same way, so that there is nothing but water to run off thru the drains. In this connection, however, there are ome things not eractly pleasant to American olfactory and optic senses. One of these is the cess pool that is too often found at the readside. It is usually made after the fashion of a cistern and cememted, is from three to five feet in depth and about the same in diameter. In this the peasant stores all the human faecos during the fall and winter preparatory to using it on the growing crop in the spring. These cess pools and the carrying of such ordure thru the streets in open buckets make one of the unpleasant, tho doubtless necessary, features of life in all places in Japan. Aside from these things tho, I remember of seeing but one dirty village or town while in Japan. This was a small fishing village on a small rocky island where little was attempted in the way of cultivation, and it was positively filthy.

One thing that strikes a Weaterner as strange in the matter of keeping things clean is the fact that al ong the gutters and at the sides of the houses etc. all grass is carefully kept 

cleared away and the ground neatly swept. It is quite common to see an old white-headed man or woman with a littlo baskot creeping along and pulling up the few sprigs of grass or weeds growing along the side of the house or street.

Suffrage. Univeral franchise daes not exist in Japan. The following conditions must be met before a man is allowed a vote:"(a)- he must be a citizen of the Fmpire; (b)- must have attainod his majority: (c)- must have lived for more than two years in the same community and bear a share of the tax burden;(d)- he must have paid the land tak or other direct taxes more than two years; (e)- he must not have received, for more than two years, any relief from public funds." 1 a "citizen", however, must have completed his twenty-fifth year and have a househola. 2 A 'citizen "is under obligations to fill any honorary office to which he may be elected or appointed, and except for certain specified reasons he can not decline official service without being subject to suspensi on of citizenship for from three to six years, together with an additional levy, during the same period, of from one-eighth to one-fourth more than his ordinary share of contribution to the city expenditure." 3 The term "direct taxes" used above applies to tax on land, income or business, and this tax must amount to at least $\$ 1.50$ per year to give the right of franchise. There are about $2,000,000$ voters in the country.

1. Iocal Finances in Japan,p. 12.

2. A Handbook of Modern Japan, p. 139 

ICAL FEATURES OF VILLAGES.

ral Appearance. Perhaps the most common general appearance of the village is that of small lightly built, thatched frame buildings, with few exceptions one storied, arranged along a single stroet. This is usually by no means straight but conforms to the road which probably existed before the village began. If there be other street more than likely there will be no two of them parallel and they will meet at all angles. The width of the street is commonly not the same throughout, and is never wide, twelve or fifteen feet perhaps being about the ordinary width.

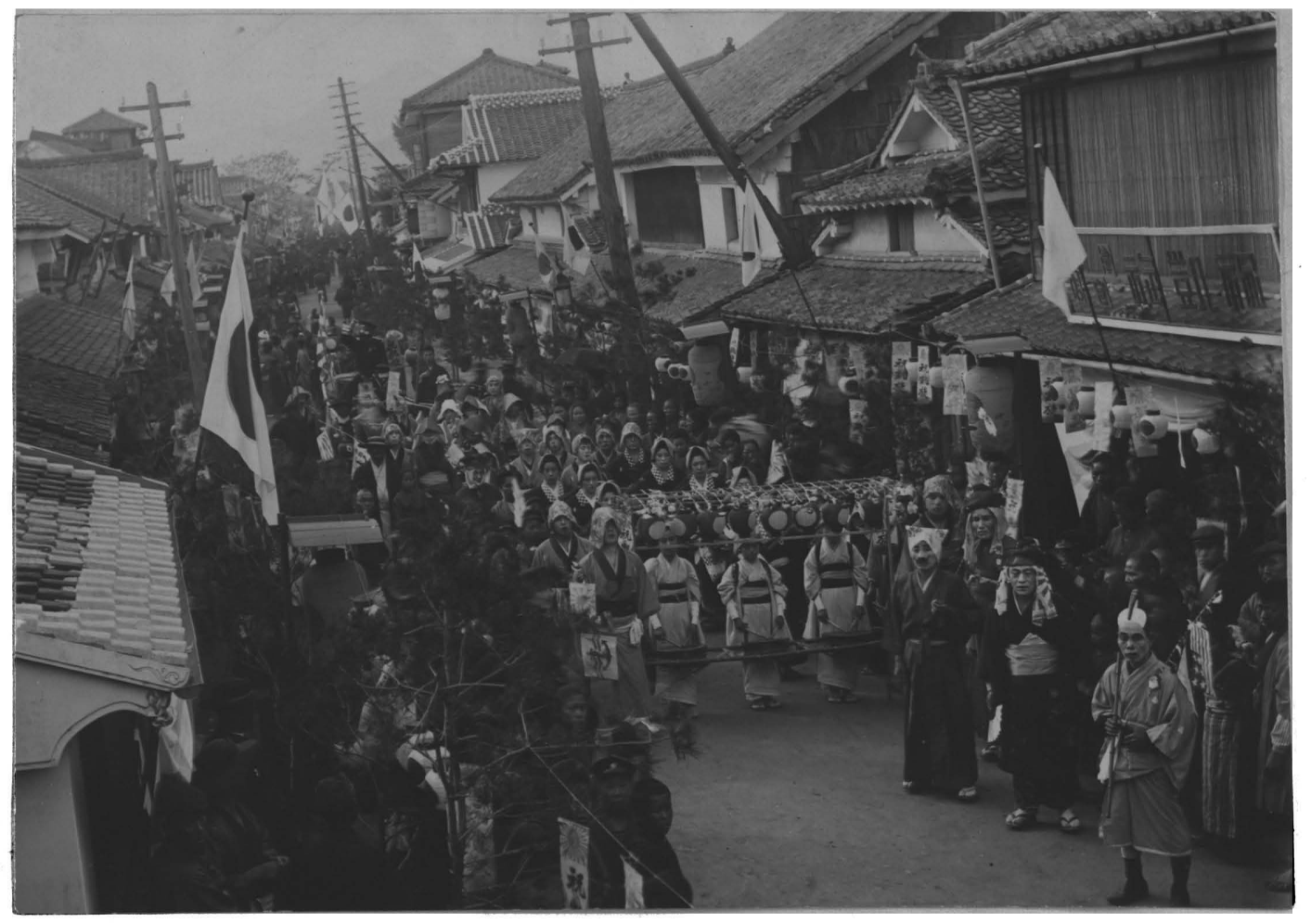

A street in Tokuyama at the time of the celebrations in honor of the fall of Port Arthur. This shows the width of the street, the style of houses, the special decorations at the sides of the street and a procession. Those in the procession, including the men standing directly in front, are dressed more or less grotesquely, especially in the matter of head-dreas. 

"The entrance to a village is often marked by a high monnd of earth on each side of the road, generally surmounted by a tree; or perhaps the evidences of an old barrier are seen in the remains of gate posts or a stone wall". ${ }^{1}$ "The prospect of a Japanese city (or village) from a height is monotonous- not a tower, not a dome, not a minaret, nothing aspiring heavenward, save in cases a painted pagoda, half hidden amidst the trees which it barely tops- nothing but long, low lines of thatch and tiles".2 The villages vary greatly in their appearance; some are extremely trim and pretty, while others give every evidence of poverty, with poor houses and dirty children.

This account of the general appearance of a Japanese village would, however, be incomplete without a description of an ordinary shop or store. "The building is, perhaps, a small, low, frame structure, crowded among its fellows on a narrow lane. The floor is raised a foot or so above the ground, and is covered as usual, with thick matting". The goods for sale are spread out on the floor or arranged on shelves or tiers- usually filling up all the room except the small space where the shopkeeper sits by his fire-box, smoking and warming himself or fannirg, according to the season. "He greets you with a profound bow and most respectful words of welcome, but makes no attempt to effect

1. Japanese homes and Their Surroundings, p. 4 F. S. Morse 2. Things Japanese, p. 34 . 

a sale, or even to show an article unless you ask to see it." 'On the other hand you will usually be served tea and provided with a tobacco tray and treated generally as a guest." "Whether you buy littlo or much or even nothing, you are always dismissed with 'Arigato gonaimasu' and'Matairasshai', which are very respectful phrases for 'Thank you' and 'Come again". I

Houses. As are the shop so are the houses in general. All in all they are at first, if not always, a disappointment to western people. To begin with there is no foundation-as we think of a $\therefore$ foundation- only a few stones laid on the ground, not in it. There are no doors and vindows according to our use of these terms and ro chimneys. They use no paint and consequently do rot have the bright colors to which we are accustomed.

The ordinary Japanese hovse is a light frome vork structure iith a heavy straw-thatched, tiled or shingled rook. Usually two or more sides have no permanent walls but are furnished with sliding wooden doors, called amado or "rain doors", which slide in grooves above and below and are closed at night or in stormy weather, but which are at other times kept pushed back to one side into a boxlike receptacle for them, These amado have no windows in them and so when closed make the house dark.

The inner walls, usually about three feet from the outside, are composed of sliding lattlce frames covered with white translucent paper. These also run in grooves and can be pushed to one side or entirely removed. The partitions within the house

1. A Handbook of Modern Japan, p. 25. 

are likewise of these paper-covered lattices, shoji, or the same covered on both sides, with thick opaque paper, fusuma. These can also be pushed to one side or removed altogether. So that the whole house may easily be thrown into one large room open on two or more sides to the free air of heaven. Where external walls appear they are made usually of bamboo lath, tied to the uprights with straw ropes and plastered inside and out. The outside may sometimes be covered with boards, unpainted or painted black. The floors are made of rough boards covered with tatami, straw mats $3 \times 6$ feet, and about two inches thick. "In as much as on these mats the Japanese walk, sit, eat, work and sleep, it is necessary to keep them very clean. They are carpet, chair, sofa, bed, table, all in one, and must not be soiled by dirty sandals, clogs, shoes, or boots, all of which are, therefore, to be removed before entering the house. ..... A room in a Japanese house seems to an American to be comparatively bare and plain, as it is devold of furniture and bric-a-brac. There is no stove, for only a small box or brazier, containing a few pleces of charcoal in a bed of ashes, is used for heating purposes. There are no chairs or sofas, for the Japanese sit on their feet on the floor. There are no huge bed sets, for they sleep on thick padded quilts spread on the floor at night, and kept in a closet when not needer. There is no large dining-table, for each person eats sitting before a small, low lacquer tray or table, about a foot high. There is no dazzling array of pictures and other ornaments on the wallonly a lakemono (apainted or written scroll) or two; and there are no miscellaneous ornaments set around here and there- only a vase of flowers." 1 There is one other feature of a Japanese house 1. A Handbook of Modern Japan, p. 52 

that must not be omitted for it "may be safely warranted to change a grumbler, who believes Japan to be a wretched hole of a barbarian country, into a rhapsodist who is ready to swear that the same country is a paradise, within ten minutes."1 This wonderful thing is called a kotatsu. It is nothing more than a little place in the floor where a fire of charcoal can be kindled, but the charm of it comes when a kind of frame is set over the fire and a thick comport spread over this. Then to come in on a winter's day chilled all thru by the damp atmosphere and to"sit under" around the kotatsu is a pleasure indeed. It is also put to another very worthy use. At night the bed is made so that the feet may come close to this fire and the weary traveller may dream of charming fire sides in his own native land.

The best rooms of a Japanese house are generally found at the rear and look out up on the "gerden". To rightly describe Japanese gardens is more than I can attempt in this paper for the subject is too big. Mr. Morse in Japanese Homes and the ir Surroundings" devotes twenty-two pages to gardens and I refer the reader to his admirable work. The space used for a garden may be of any size from a small dish set on a table or in the raised alcove at the side of the room-the Tokonoma-to many acres in extent. Yet largely the same features will be preserved in all. "The Tokoniwa is usually made in some curious bowl, or shallow carbed box, or quaintly shaped vessel impossible to describe by any English word. Therein are oreated minuscule hills with minuscule houses upon them, and microscopic ponds-and rivultts spanned by ting humped bridges; and queer wee plants do duty for trees, and curiously formed pebbles stand for rocks, and there are tiny

1. The Mikado's Fmpire, p. 414. 

toro (stone lantern), perhaps a tiny torii (FF) as well, - in short, a charming and living model of a Japanese landscape."l A landscape is almost the only thing attempted in a Japanese garden and this is often in imitation of some famous natural scene. Iandscape gardening has become a fine art with them and the expert is able to make his garden symbolise such abstract ideas as peace, chastity, old age etc.

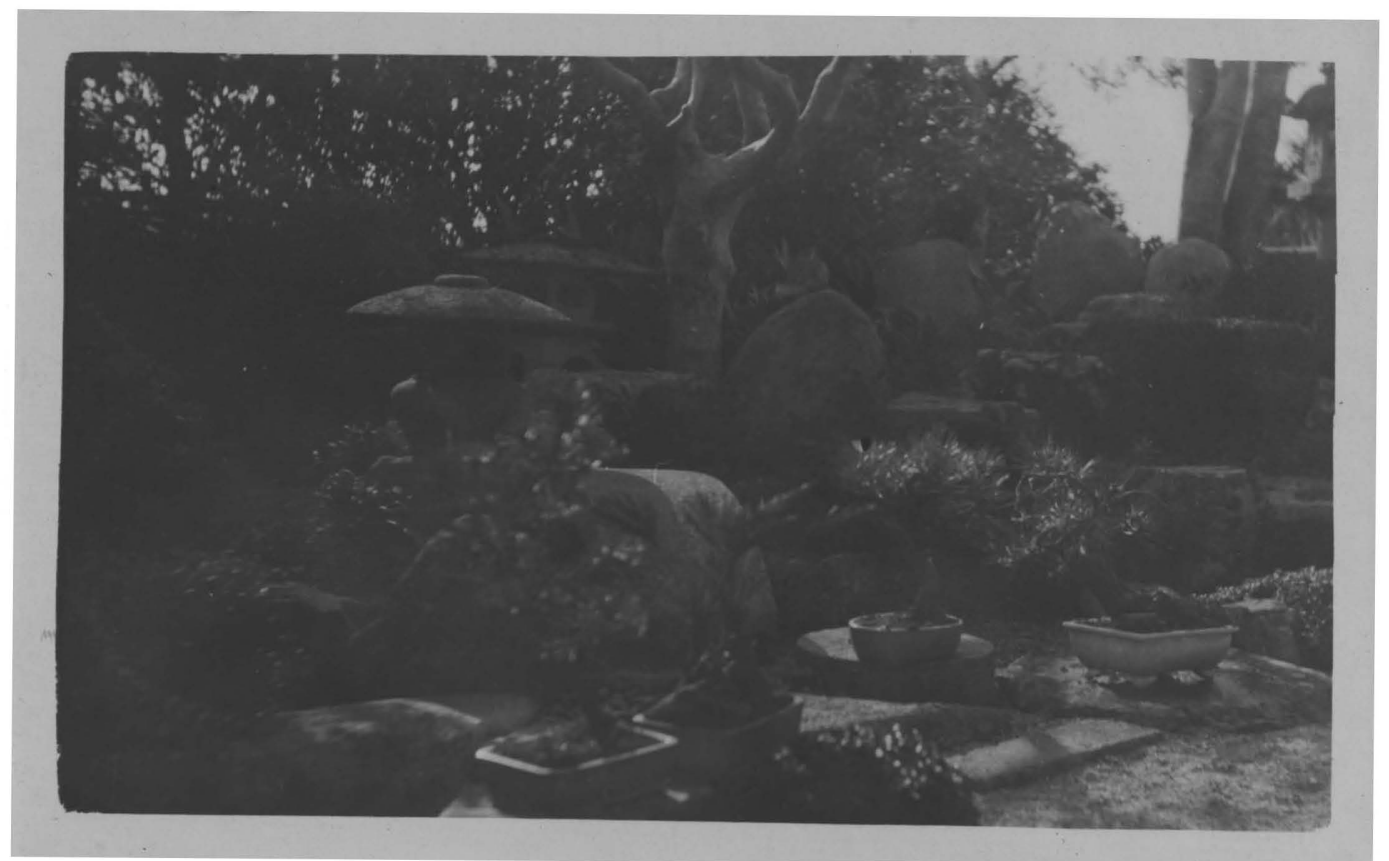

1. Things Jupanese.

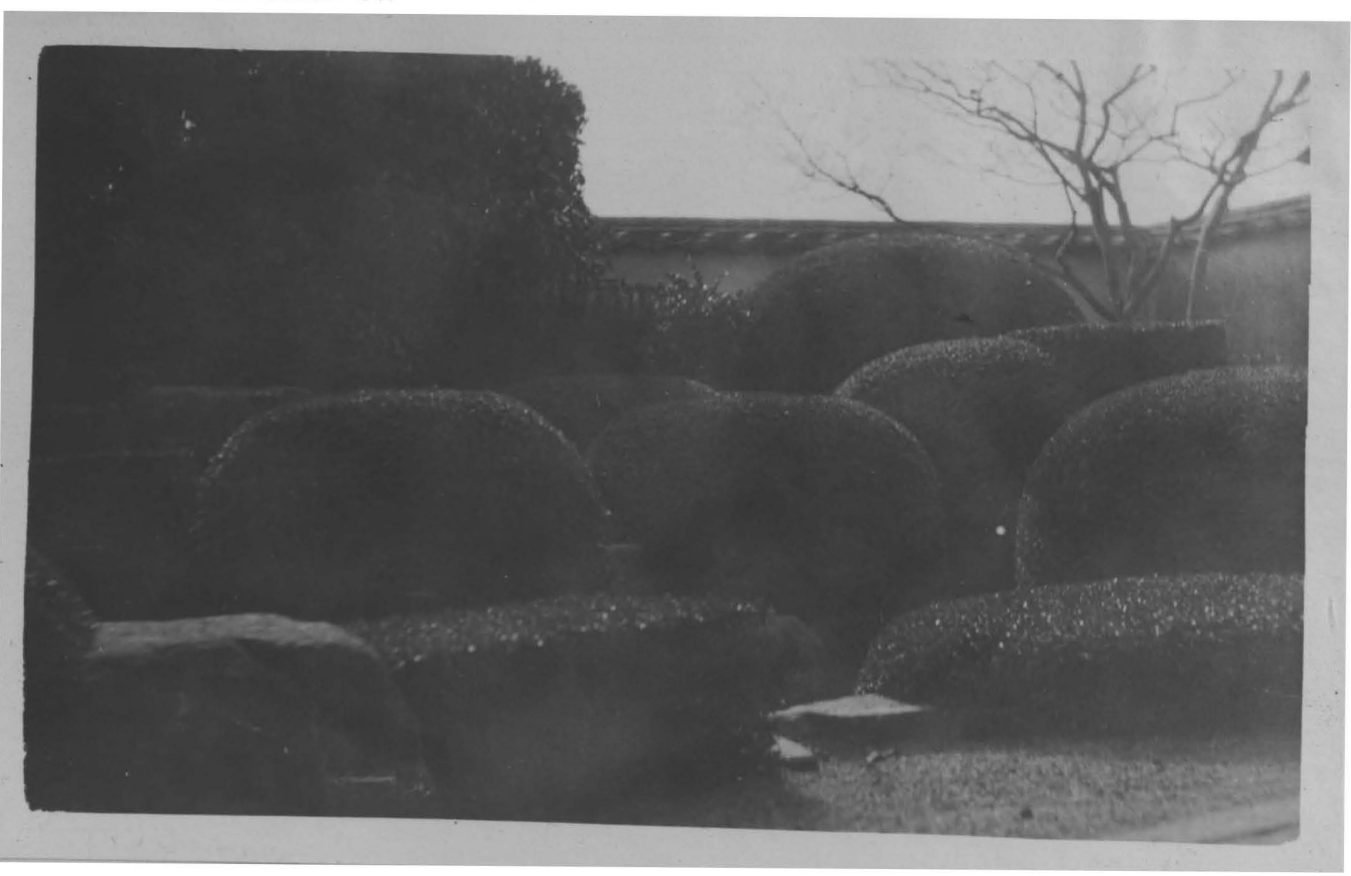



RTGUTATIONS.

We have said above that Japan had no written laws, ? properly speaking, until after the Restoration- yet we find numerous regulations issued from time to time both for and by the villages. Amongst the papers of Dr. D. B. Simmons, who lived in Japan almost continuously from 1859 to 1889 , are found translations of eeveral such codes of regulations. ${ }^{1}$ Many of them have nothing to show the place nor the date of the originals and for scarcely any of them can the originals be found and yet the scholarship and intergrity of Dr. Simmons were such that we cannot doubt but that they are bona-fide. The followIng "Rules of mura (villages) issued in 1721 by Shogun Yoshimune" are from Dr. Simmons collection.

1. In every mura the people, including both large and gmall farmers, should organize into gonin gumi, in a permanent

1. Transactions of the Asiatic Society of Japan, Vol. XIX Pt. I 

and thorough manner, and for the sincere observance of the laws. In case any dispute arises, it must be taken into consideration by the gonin gumi.

2. All meetings of the people for conspiracy and sedition and all arinking together of the cup of water is forbidaen. (It is a custom when going to war, to a duel, or on any dangerous errand, to arink a cup of pure water and repeat a prayer to the gol ov gods of the mura for success in the undertaling. I

3. Farmers who have ten tan (a tan is about one-fourth of an seret or less of lend are forbidden to divide it among their chlldren. Any land over this amount may be divided.

4. Wills of land are void without the seal of the nanush (viliage headman).

5. No one is to alter the size of his house without permiasion from the dalkwan (magistrate), but merchants are excepted from this rule.

6. No one is to cultivate now lands without permission.

7. Holding new matsuri (a religious festival) and getting wp great excitement at a matsuri is forbidaen.

8. Irand must not be sold.

9. The secret sale of land in the neme of another is forbidar.

10. Heretofore there has been no limit to the length of time for which land could be mortgaged. Ten years is now fixed upon the the limit.

11. If a manushit wishes to mortgage his land, the seal of the ranf-gahira and the toshiyori (the elder of the fillage are necessery. 

12. Secret aale by way of mortgage is forbidden.

13. On the death of a mortgager, only a son or grandson can redeem it. If such a one has been adopted by another family, he too is excluded.

14. All must examine carefully the tax list of the mura posted at the narushi's residence.

15. When one comes into possession of land by descent he must immediately report it to the nanushi.

16. If when a new survey of land is made, a portion is left over, it must not be divided by the mura but must be reported 17. Speaking disgraceful things of another man, or publicly posting him as a bad man, even if he is so, is forbidden.

18. When a forest is resorted to by the farmers for leaf manure its onfoyment must be arranged in common; no one is to take more than his share.

19. A kosakt (laborer) who has held his land for twenty years cannot be dispossessed.

Again we find a "Proclamation issued by a new daikwan: to the people."

1. All laws of the Government and all the good measures of the previous daikwan I promise to observe, as also the various old customs relating to the privileges of the sea-board.

2. I will carefully search for all Christians in the manner already customary.

3. All persons are forbidden to cut trees in the forests without permission.

5. No new comers wishing to rent land or become servants who have not the certificate of the priest of their section

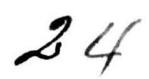



declaring that they are not Christians, can be allowed to settle. Theatrical performers and showmen and persons having no nimbetsucho (a ticket showing a record of their registration in their home parish-temple) are forbidden to remain in the village.

6. In regard to the villages where the Shogun goes hawking- birds are not to be erightened and strange dogs are to be tied up.

7. All are warned to be prompt in the payment of the tax. Whoever fails will be imprisoned.

8. If there is a fire in a neighboring mura, all must turn out and assist. Those who do not are to be reprimanded.

9. When an alarm of robbers is given, all must immediately go to render assistance. Whoever does not will be reprimanded.

10. Gambling of all kinds, lotteries, and cock-fighting are forbidden.

11. Guarrels and fights are bad and should be avoided. But if a fight occurs and some one is injured, the loogl officers should detain the parties and report to the daikwam:

12. If a traveller, even a beggar, is taken sick so that he cannot proceed, the local officers must call a doctor to give the necessary care and report to the daikwan .

16. Farmers are not to wear two swords.

18. Villages given to lew suits are always poor. If trouble occurs, all efforts should be made to settle it by arbitration.

19. The tax levy, as adjusted by the daikwan, must receive the assent of every farmer, even the smallest, witnessed 

by his seal upon the document.

20. Estimates of mura expenses must be made up with the greatest economy and must be assented to by all the farmers. When mura officers travel on public business, their expenses are to be estimated on a fixed scale, and no extras are to be allowed. (On receipt of this notification by the farmers, they sent the following answer:-

"We have examined each of the articles and we subscribe to them. If we break any of the rules, we will accept without protest the punishment, whatever it may be, that jour displeasure may inflict.

In witness whereof we affix our seals".

Reference has been made several times to the Kumi or the Gonin Gumi as it is sometimes called. Among Dr. Simmon's papers were found several specimens of Kumi-cho or Kumi regulations. The following is a sample. There are fifty-three articles in all so that I have chosen only those that seem to be of most interest.

A Kumi is formed by uniting the five families that are nearest to each other (of whatever class they are).

3. If any member of a kumi, whether farmer, merchant, or artisan, is lazy and does not attend properly to his business the hangashira ( kind of essembly) will advise him, warn him and lead him into better ways. If the person does not listen to this advise, and becomes angry and obstinate, he is to be reported to the toghizori (village elder). As fathers, sons, members of families, relatives and fellow villagers, we will endeavor to live in peaceful and kindly relations; as members of a kumi.

$$
26
$$



we will cultivate friendly feelings even more than with our o relatives, and will promote each other's happiness as well as share each other's griefs. If there is an unprincipled and lawless person in a kumi, we will all share the responsibility for him.

9. We will not buy any of the property of temples nor take a mortgage on it.

11. As nanushi we will buy and wear silk and build fine houses, but will not otherwise indulge in luxury and extravagance.

13. At the time of a great wind-storm, rain-storm, drought, or visitation of insects, the Government, as is the custom, may give food to starving farmers, or those who are well off may lend food or seed to the mura; still, if the misfortune should continue for years, even the Government could not continue to supply us. For this reason we will try-all who canto store away some of our surplus crops, if any.

$$
\text { 20. So far as possible we will choose for adoption }
$$
those who are relatives or members of the family. But if only a female remains, and there is among the relatives and family members no male of proper age, then we will select from without. If there are three or four sons, and the eldest is sickly, or is incorrigibly bad, inkind to parents, and disobedient, and the father thinks he is not justified in making him the heir, he can make the second or other son the heir upon consulting with the kumi and reporting to the nanushi. (In accounting for such a regulation one must remember that the most important duty of any head of a family was that of providing for the continuance of the family ancestor worship-and only male, the legal hoad of the 
family,could do this l.

23. If any one goes away to a neighbofing mura to remain over three days, kumi. nanushi and toshiyorl will be inforned; the same notice will be given on leaving for a distant place to take service, on business or for pleasure.

24. Io person not having a nimbetsu-cho is allowed to remain even one night in the mure.

25. Any person coming from another part of the country and asking permission to live in the mura will be permitted to do 80, on giving his nimbetsa-cho and naming a responsible person for his security.

31. Children are not to be abandoned, no matter how poor the parents. :

The following are taken from the kumf cho of a tillage near Kyoto.

2. We shall require children to respect their parents, servants obey their masters, husbands and wives, brothers and sisters, to live in harmony, and the young to revere and cherish thir elders,- In short, we will endeavor to lead the people to Walk righteously.

5. Each kumi shall carefully watch over the condut of its members so as to prevent wong doing. Whenever any person is found to have misbehaved, and his kumi have negligently failed to discover it, the kumi shall be considered oulpable as as well as the nanushi and the toshiyori.

10. All annual taxes shall be paid in full on the twentleth day of the twelfth month. Fajment of all debts whether of money or of rice shall be postponed until all taxes are fully 

paid.

21. If any person falls ill and his family also, so that his land is not cultivated, his kuml and the people of the mura shall work the land so as to produce the amount of his taxes. If they fail to do so they shall be responsible for the taxes. Orphans shall be supported at the expense of the mura.

As is evident from the foregoing regulations, the things prescribed that a man must do were many more than those he must not do. In faot it is noticeably true in Japanese soclety to-day that the individual is beset on every hand by rules and customs innumerable and to fall to observe these means social ostracism, even when it does not involve more serious punishment. The ahild, and particularly the girl, is trained from youth up to carefully observe the many, many rules of propriety, in the family, among her Iriends and relatives, and toward guests eto., etc. She is continually reminded of her position and her relations to those about her and what those relations will be whes she is married and comes to live in the home with her husband's parent8.

A8 was said above police regulaticns are almost innumerable. 

四E PEOPIE.

But let us turn for a moment to the people themselves and notice a few of their general characteristics. The People and Dress.

Physically the Japanese are, as is quite well known, much smaller than almost any other people, the ndiamond edition of humanity", as some one has called them. This is particularly noticeable in the shortness of the legs. Mr. Chamberleitn groups their physical characteristics very well by saying that "the average Japanese has a long body and short legs, a large skull with a tendency to prognathism, a flat nose, coarse hair, scanty beard, puffy ejelids, a sallow complexion, and a low stature"l He likewise sums up their mental characteristics. "The average judgement formed by those who have lived some time among the Japanese, seems to resolve itself into three principal items on the credit side, which are cleanliness, kindliness, and a refined artistic taste, and three items on the debit side, namely vanity, unbusinesslike habits, and an incapacity for appreciating abstract ideas." 2

1. Things Japanese, p. 250

2. " " p. 262 . 

As regards Japanęe dress it is perheps not necessary to say much, for every one is more or 1088 acquainted already withthi kimono, tho in semi-foreign style. The kimono is the principal feature of dress with both men and women, and for ordinary wear about the house or when working one or more of these constitute the olothing. But on dress ocoasions a kind of divided skirt (hakama) is worn by men, and an outer ooat (haori) which usually reaches about to the kneos, and bears in several places the family orest. A great deal of silk is worn, in faot no Japanese consiaers himself at all properly aressed for anj occasion requiring good clothes anless he has on silk, and it is astonishing to seo how many of the poor peasants even will come out on some ceremon1al ooossion dressed in silk. This fact is in their favor-if they onoe get a good suit of alothes it nover goes out of style, and then they are very careful about taking care of their olothing. Even in the smill oountry viliages, however, one will find many who wear thropean olothes, partioularly among officials and teachers; and tallor shops are found evergwhere. One finds not uncommonly some ludiorous combinations of half Baropean, half Japanese make ups, and the Buropean clothes are not always worn just as Westerners wear them. I oite the following devoription as being, porhaps not tjpical, but not so seldom found as ono might judge. He was the business manager of a school. "H1s coat was of the full frook or 'Prince Albert' cut, the material was alpaca. When unbuttoned it discorered a waist-coat that once had been ouitable for orening dress, and albo the upper half of a shirt front to which the ingenious construotor had affixed a collar and a bright groen tie. The tie had worked round under 

the coat collar, or I might have noticed it before. What was between him and that shirt front I could only guess. It might have been a liver pad with sleeve attachments. His trousers were Iinen, but whether the right leg or the left leg preserved the original shade I could not say. There was a marked difference between the two. As he had taken off his shoes on entering the house I noticed that he wore mittens on his feet". 1

Customs.

In a country isolated as Japan has been thru so much of her history from all the rest of the world, it is to be expected. that the customs of the people should be very different from those of other people. In fact it is the cormon thing for Westerners to speak of Japanese customs as representing topsy turvydom. The following examples will suffice to show how true this saying is:what we speak of as the Christian name is with them always spoken after or written the family name, the title San (Mr., Mrs., or Miss) is likewise spoken or written after the name. In addressing a letter the name of the prefecture (or state) comes first, then the city, street and number-and lastly the name and title of the person. On the reverse of the envelope will appear always the address and nome of the writer. Writing or printing begins at the upper right hand corner of the sheet and proceeds from the top to the bottom, instead of across; the front of the book is therefore where the back would be with us, and the footnotes occur at the top. All dates are spoken or written thus, first the name of the reign or era, then the jear, the month and the day of the month; e.g. Meifi, 40th year, 10th month, lst day (Meiji.

1. The Heart of Japan, p. 293. C. I. Brownel1.

$$
32
$$



Shijunen, Jugatsu, ichinichil. All roads lead up to Tokyo and all traing running toward Tokyo are up trains and those in the opposite direction are down trains, without regard to direction or al titude. The best part of the house and of the premises will be at the back. Another thing worth mentioning here is that there is very little change in fashions in dress. A not uncommon custom is for a woman who has some idle capital to invest it in clothing and lay them away for future use- not fearing they will go out of fashion. Dr. Arthur H. Smith in his "Village Life in China" has a chapter on "New Year in Chinese Villages" and I find so many aspects of the New Year in Japan are so near the same as what he describes there that I shall mention a few of the things most common at New Year's time in Dai Nippon. No family, however poor, would think of passing this important season without mochi to oat. Moch1 is a special kind of rice cake, very delloious and indulged in only once or twice a year. As far as possible all members of the family must have new clothes for the New Year - and there must be new mats for the floor and things generally given a good house oleaning. Early in the morning on New Year's day come the religious ceremonies at the home and a visit to the temple, usually by all members of the fumily. For the first three days there are all manner of social calls to make and to receive. All one's friends and relatives must be remembered either by presents or calls or both and there are congratulations for everyone. During these days work of all kinds almost is at a stand still- the nation is at leisure and is enjoying itself at home. During the few days preceeding New Years all debts must be paid as this is the reckoning time of the year 

and it is a very serious matter if all debts cannot be settled at this time. In olden times, and of course to some extent jet, one found the custom which probably marked as clearly as anything the place of the nation in civilization, that of the very close relation of the individual to his home community, indeed he had no legal existence outside of his native village or parish and sad was the lot of the man who was banished from his own family and commune. He was an outcast and found lodging only with the greatest difficulty in any place.

To a Westerner a funeral presents some strange features. To begin with, white is the color for mourning. The coffin is a small square box into which the corpse is placed in a sttting posture, with the head bent to the knees. The funeral services are of great length and intricacy and vast sums of money are often spent on feasts etc., for after the interment many guests - return to the stricken home to partake of the bountiful feast that is made by the family. Fvery guest when he comes, or every relative or friend of the family whether he comes or not, is expected to bring or send some present, vsually in the form of food or money. In the funeral procession the coffin is carried by poles fastened to it and borne on the shoulders of four men, bunches of large artificial flowers are carried in large, wooden vases etc., etc. 



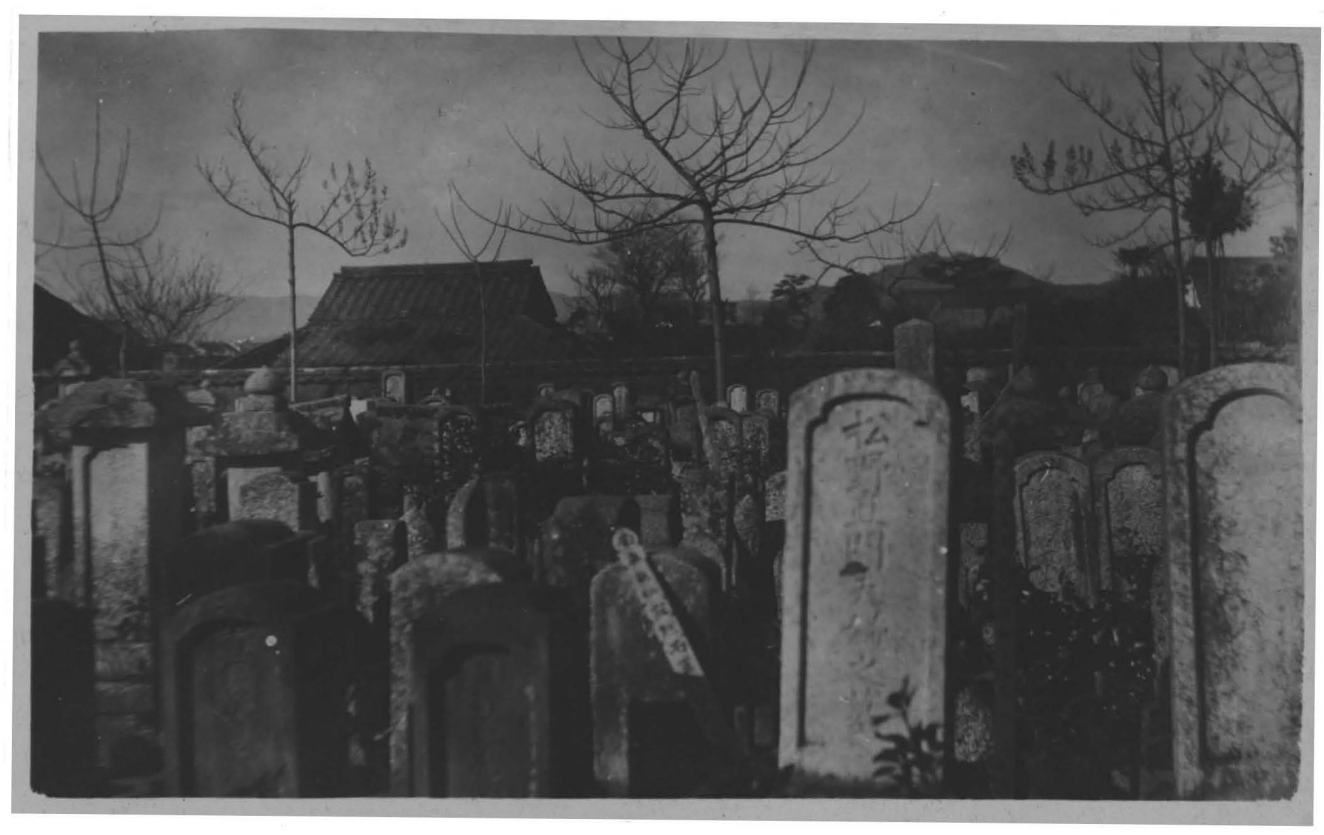

A Buddhist grave yard.

It may be well to note that these customs mentioned above are found more particularly in the villages than they are in the larger places, for one must remember that the cities are being rapidy Westernized in very many ways, so that many of the se peculiar customs are being laid aside. 

OLITERESS.

Not unoommonly do we hear it said that the Japanese are the most polite people in the world, and if we mean by politeness conforming to correct etiquette and good manners this is certainly true, but if we inolude the feelings which prompt the outward acts then I am not sure. Mr. Gulick, in his "Evolution of the Japanese" declares they do rightly only those things they have learned, (and some orle else/has compared the courtesy of the Westerner with that of the Japanese by claiming that with the former courtesy seems to flow from a good humored sense of what is due to others; but with the latter from \& high foeling of what is expected from himself. Of course, with Mr. Hearn, we may admire their gentility of manner tho it is prompted by a different motive than our own. "The old kindliness and grace of manners need not cease to charm us because we know that such manners were cultivated, for a thousand years, under the edge of the sword". ${ }^{1} \mathrm{Mr}$. Chamberlain, however, in his "Things Japanose" takes the opposite position and says that Japanese politeness is "something more than mere-bows and smiles,-that it is rooted in genulne kindliness, especially among the lower classes".2 Perhaps another way of looking at it is that brought out by a quotation from Dr. Nitobe, "The end of all etiquette is so to cultivate your mind that even when you are quietly seated, not the roughest ruffian can dare to make onset on your person..... It means that by constant exercise in correct manners, one brings

1. Japan-An Interpretation, p. 502 .

2. Things Japanese, p.382. 

all the parts and faculties of his body into perfect order and into such harmony with itsolf and its environment as to express the mastery of spirit over the flesh".1

I do not care to risk my judgement in deciding which of the above theories is correct. I think, however, that one would not be far wrong if he said both were right in a sense, for it certainly seems to me that, with a large number of Japanese at least, they are as kindly disposed at heart as we can be and that their aots of kindliness spring from a desire to do something for the other fellow. On the other hand it cannot be denied that many of them do act in polite ways purely from a self-centered motive, but do we 7 not the same? The Japanese has this in his favor that in the ordinary daily matters of life he has been trained until he knows better than we what are the proper ways of doing thinge, after his own standards, whereas in 80 many things we let the purpose stand for the deed and act every man to suit his own pleasure.

I will cite two instances which show, so many claim, that the ordinary Japanese is not polite, according to our way of looking at things. Most railway coaches in Japan have seats running along the sides the whole length of the coach and this affords a very comfortable place to lie down. It is not at all uncommon to see a Japanese man lying comfortably stretched out on one of these seats while others are standing in the aisle because these is no room to sit. It does not seem to occur to him that it would be a polite thing to sit up and allow the

1. Bushido- The Soul of Japan, p.32. Dr. Nitobe. 

others the use of part of the seat. Again, once when a Japanese lady of some rank was calling upon a foreign lady in a Japanese house, she found, on entering, that her hostess was not sitting where custom dictated that she should sit, so she deliberately turned her back upon her and made her proper obeisance toward the place where the hostess ought to have been.

Again I think it is safe to say that what we are likely to think of as being the extreme politeness of the Japanese is found more commonly in the villages than in the cities. There formal etiquette with its striot regulations as to just how many bows must be made and the prescribed angle to which the body must be bent and the length of time each bow shall last and the proper one to assume the upright posture first etc.all such things, I think we are safe in saying, are much more (thorply/carried out in the country-for there is old time Japan. 

F)OD.

Iike most other nations, the Japanese take three meals a day. Much the ame food is partaken of at all these meals, tho breakfast is lighter than the other two. The staple is ricewhich is replaced by barley, millet or some other cheap grain in the poorer country districts. Rice, with fish, either raw or cooked or both, one or more kinds of soup, minute portions of one or two vegetables, and some kind of pickles make the common meal. Very little meat is eaten, but the soy-bean is of all vegetables the nearest to meat in point of nutriment. These and other legumes alone or with eggs take the place of meat, and besides being eaten in the natural state they are made into sauce, vegetable jelly etc. Starch producing bulbs or roots such 88 the lotus, arrow head and sweet potato are found in large numberseren as many as from fifteen to eighteen kinds, but it is seldom if ever that one sees the common Irish potato or many other of $a$ our most common regetables-e.g.-cabbage, tomatoes, radishes, lettuce, onions eto.

The bererages in common use at meal time, as well as at other times, are tea, which is taken without sugar or milk, and sake or rice wine, which is often drunk hot and at the begining of the meal instead of at the end as with us.

The methods of cooking are altogether different from our own and it is with great difficulty that Wersterners eat Japanese fodd at first. "Japanese dishes fail also to satisfy European cravings. Imagine a diet without meat, without milk, without bread, without butter, without jam, without coffee, without alad or any sufficient quantity of nicely cooked vegetables, olthout 

puddings of any sort, without stewed fruit and with comparatively little fresh fruit, the European vegetarian will have almost as much difficulty in making anything out of it as the ordinary meat eater."l The food is clean, often pretty to look at, and has a certain poignancy to it that makes one crave for a taste of it after he has grown accustomed to it. This is borne out by the fact that most western people in Japan form the habit of taking a Japanese meal once every week or so, but for a steady diet- no, rot only is there a lack of our own kinds of food, but also of the great number of dishes that we see on our own tables.

Where several eat together at the same table, as in the home or where a number of students or other groups eat together. the only dishes required are a rice bowl and a pair of chopsticks and one or more small side dishes for each individual, and the rice bucket sitting in the middle of the table and one or more large dishes of vegetables and the ever present bowl of pickles. In hotels, however, and also not uncommonly in the home, each individual is served separately on a small table some eight or ten inches high or simply on a platter, in his own room. With the better clesses wooden bowls, highly lacquered and very elegant are in more common use than porcelain.

"Most Japanese towns of any size now boast what is oalled a seiyoryori, which, being interpreted, means a foreign restaurant. Unfortunately, third rate Anglo-saxon influence has had the hand here, with the result that the central idea of the Japano-European cuisine takes consistency in slabs of tough beef-

1. Things Japanese, p. 179.

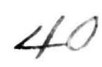



steak anointed with mustard and spurious Worcestershire sauce. This culminating point is reached after several courses- one of watery soup, another or fish fried in rancid butter, a third a chicken's drunsticks stewed also in rancid butter; and the feast not infrequently terminates with what a local cookery book, unhappily disfigured by numerous misprints, terms a 'sweat omilette'". 1 Restaurants and inns where food and lodging after the native fashion are provided are found everywhere, from the smallest villages ur, and the rates are often extremely cheap. It is possible for a working man for example to find a lodging with supper and breakfast for a very few sen. The old time custom at the inn, and one which is not infrequently met with in country places to-day, was for the bill to be made to cover the bare cost of things used by the guest. He was expected then to add to this amount all the way from one-fifth to one-half more as chadai (literally tea money). A man was judged by the amount of chadai he gave, and if this was very Jiberal he had a visit from the head of the establishment to express thanks for the same, and when he departed all would assemble to see him off and the highest servant would carry his luggage etc.

1. Things Japanese, p. 181 . 

IIE FAMIIY.

Marriage. Marriage among the Japanese is less a personal and more of a family matter than with us. Religion has nothing to say in the matter, and law almost nothing. There is no courting, no license, no church wedding, no preacher nor other official, no honey moon- and not much assurance that there will be any permanency to it. The procedure is something after this manner. When the child-boy or girl-has reached a marriageable age it is the duty of the parents to see that a suitable partner is found. This however is not done directly by them but thru some relative or friend who acts as "middle man". He not only arranges the marriage, but remains thru life a sort or adviser to the young couple, a referee to whom disputes or misunderstandings may be submitted for arbitration. After havIng found a suitable parti the middle man arranges for a mi-ai or "seeing meeting" at some theater or party and the prospective bride and groom have their only chance, it may be, to determine their like or dislike for each other- tho sometimes of course they may happen to be already mutual friends. If both parties are satisfied with this "seeing" and sometimes. even if they are not satisfied, gifts consisting of clothing, or money to purchase clothing, and certain kinds of food are exchanged- this constitutes what corresponds to our bet/hrothal This is followed within a few days or weeks perhaps by the wedding. Stripped of it unnecessary details this consists of 

the bride going to the groom's house and there, seated opposite him on the floor, drinking three times three sups of wine from three cups. This and the transfer of her name from her own family register, at the government office, to that of his family and the marriage is complete. ${ }^{1}$ There follow as with us various feasts and visits etc.

The Family. The subject of marriage naturally leads one to think of the family. With us the individual is the social unit and the family is a union of individuals, not so in Japan-for there the family has been, and is very largely now, the unit, and the individual is worth consideration only by reason of his connection with the family. "The only way in which individuality before the law can be obtained by man or woman in Japan is thru cutting the tie that binds to the family, and starting out in

1. I refer any who are interested in any phase of the Japanese marriage to $\mathrm{Mr}$. Tamura's splendid little book "The Japanese Bride".

It is true that in many of the large cities marriages patterned after our own customs are frequent, but in the villages the above form is all but universal. 

Iife afresh as the head of a new family.-... It seems likely that thru this means an evolution from the family to the individual sjotem will be effected." Mr. Hearn is responsible for the following:- "The Japanese family in early times meant very much more than 'household': It might include a hundred or a thousand households;-.- the patriarchal family in the largest sense." 2 . This family was held together by the influence of ancestor worship. It was the solemn obligation of each member of this large family to be loyal to and uphold the worship of his ancestors. Yea even more- his own welfare and that of the femily depended upon the welfare of their dead, therefore the offerings of food and the prayers before the tablets of their dead. The food was-to sustain them and the prajers were perhaps, as much as any thing, communion with them- it was necessary to keep them informed of the doings of the living.

fistor Worship. This matter of ancestor worship is responsible for many things in the organization of society. The family line must be continued at all cost, else the dead would be left in a deplorable condition since their heppiness or misery depends very largely upon the worship of their progeny. Furthermore the family cult coan be carried on only by the male head of the family. The woman it is true shared the cult, but she can? not maintain 1t. It is consequently the sacred duty of every family to bring up a son to succeed to the headship of the fam11. If the wife ls therefore barren she nisy be dismised

1. Japanese Girls and Fomen. Alice M. Bacon.

2. Japan- An Interpretation, p. 28 

and another taken or a concubine taken into the family, for is not the continuance of the family worthy of more consideration than the individual? It is true there is the possibility of adopting a son, but the other method usually prevails. In case there is a daughter and no son, a son may be and often is adopted to become her husband and thus carry on the family. In pro Meiji times the head of the family was supreme, in theory at least, and the life and death of all members of the family was in his hands, tho in practice this was softened by common sense, as are all things in Japan. He was responsible also for the misdeeds of the family. Iikewise no contract could be made by any member unless endorsed with the seal of the head.

The Position of Woman.

The idea that woman can not maintain the family cult, together with the teachings of Budahism, which early found a hearing in Japan, accounts very largely for the position of woman in society. Her lot is often summed up in what is called the "three obediences"- obedience, before marriage, to a father, obedience after marriage, to a husband and that husband's parents, obedience, when widowed, to a son. Her duties must be always either with in the house, or, if she belongs to the peasant class, in the field.

It is not exactly true to-day that there are no vocations open to women, tho there are few except that of teaching and even in this her sphere is confined to the primary and grammar grades and to girls schools. But as early as 1898 we find 10,000 women employed in public and private schools as teachers. 

In the profession of nursing there has recently opened a field of labor for many women and in this, as in perhaps nothing else, they find themselves in a place for which their training has supremely fitted them. The new factories and the telephone and printing offices are not furnishing employment for many women.

In the home the idea of a wife's duty to her husband includes no thought of associating with him on terms of equality. She is simply the housekeeper and the mother of his children. Except in exceptional cases she is in ro sense the confidant of adviser of her hugband- is not even his intimate friend. She is, in many cases, little more than the hoad servant in the household. "In the eye of Budahistic dogma, ecclesiastical law, and monkish asceticiom, woman is but a temptation, a share, an unclean thing, a scapegoat, an obstacle to peace and holiness."I Among the lower classes, the farmers and the laborers, it is true the wife occupies a place more nearly on an equality with her husband then she does among the upper classes.

In society- tho among the class we are trying to write about there can hardly be said to be any Four Hundred- the man is considered first- he presects the woman on the street, and in entering the house, he is served first if, as is very rarely true, they eat together- and so on thru the minutiae of daily Iife.

There 18, on the other hand, another side to the life of the Japanese woman. Tho she is almost the slave to her lord

1. Mikado's Empire, p. 555.<smiles>[Te]</smiles> 

husband and waits up on and cares for him and suppresses her desires in deference to his- jet sho admirably fits her place, I know of nothing more charming, more refined, more cultured, more beautifully fitting than is the Japunese woman of the ordinary well-to-do family. Her dress, her language, her every action is so graceful and so in keeping it seems with what one is glad to see that he finds himself thinking that nothing could be better than the training which produced such a perfect individual. Dr. Takag1 of Tokyo, who has spent many jears in America and holds a Ph.D from one of our best Fastern Universities, has recently said, thru one of the Japanese newspapers, that/Japanese women possess three important qualities as highly as any women in the world. 1. They are gentle, submissive, amiable and refined. 2. They possess great strength of will. They are content to live for years apart from their husbands and this in perfect loyalty to them. The chastity of women, he says, is something marvellous. 3. The spirit of selfsacrifice and devotion is very strong among our women. 1 /

"The whole question of the position of Japanese women in history, social life, educstion, employments, authorship, art, marriage, concubinage, prostitution, religion, benevolent labor, the ideals of literature, popular superstition, etc., discloses such a wide and fascinating field of inquiry, that I wonder no one has yet entered it." 2

/Regarding the matter of divorce, in old Japan, and by

1. The Japan Evangelist, Feb. 1909, p.48. Guoted from Japan Mail.

2. Mikado's Empire, p. 557.

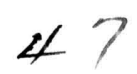



this we mean always Japan before the kestoration of ' 68 , it may be truthfully said that divorce was an easier matter than marriage, in fact the condition of affairs seems to compare favorably with the old Mosaic times when all a man had to do was to give his wife a "writing of divorcement" and send her back to her parents. The common grounds for divorce were such that a man could easily find a legal excuse for divorcing any woman whom he no longer wanted. These grounds are ugually enumerated as follows;- barrenness, adultery, disobedience to parenti-in-law, talking too much, theft, jealousy or a hereditary disease. Today of course thirgs are slowly changing and woman is coming to have some recognition before the law. It was only a few jears ago tho, 1873, that she was given the right to sue for a divorce herselfy

Mr. Gulick gives some startling figures for recent

years on this question as follows:-

Marriago- Divorce - Iegitimate child-Illegitimate child

$1890-325,141 \quad 109,088 \quad 1,079,121 \quad 66,253$

$1891-325,651 \quad 112,411 \quad 1,033,653 \quad 64,122$

$\begin{array}{lllll}1894- & 361,319 & 114,436 & 1,132,897 & 76,407\end{array}$

$\begin{array}{lllll}1897-395,207 & 124,075 & 1,335,125 & 89,996\end{array}$

I There is,however, one important particular in which the woman of Japan, in the better class families, is better situated than is her American sister, and that is that she is not compelled to do so much of her own household work since it is much easier to secure servants who are reliable and efficient. 

lomestio Servants.

It is thought by some, tho probably not fully established, that the first domestics were slaves or serfs. This is pretty well borne out by the fact that during feudal times the family furnishing servants to a household of higher rank, stood to the latter in the relation of vassal to liege lord, and between the two there existed a real bond of loyalty and kindliness, and the same family often furnished the servants in a household for generations. These came into such closer relations with the family they served that they became, as it were, a part of the family and desired no higher lot than such service.

This same spirit is noticesble in the better families to-day. True, as we say, the servant knows his place and never so much as dreams of doing anything that would show that he did not recognize his position and know how to fill it. The Japanese language is, you might say, made up of two or three languages in that by the use or non use of honorifies and different words one may regulate his speech according to the rank of the person spoken to. To the servant the master uses a stple of conversation devoid of all honorfies- such as he would not dare to use in speaking to an equal. The servant on the other hand employs the most exalted language at his command when addressing his master. The servant in Japan has been compared to the Negro in slave times in the South in this country, and the comparison gives a fair idea tho not a real picture by any means.

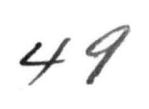



All of the better houses in Japan have servant quarters in them. The servant is therefore always on the place and mingles freely with his mater's family and does not consider it out of place at times to take part in the conversation of the family even when guests are present for, as has been said before, he is recognized pretty much as one of the family. A guest coming into or leaving a home is expected to salute the servant at the door and at all times to use the best language when adaressing them.

The servant in Japan is allowed, or expected to us his own mind. Mere blind obedience does not seem to be the rule. He is expeoted to have the interests of his master sufficiently at heart to endeavor always to do what will prove most beneficial. This doubtless came about in olden times when the more or less rigid caste system caused many men to remain in the position of servents who, in point of intelligence and business ability, outranked the master of the house. In such cases the business was often left almost wholly in the servant's hands. In fact the position of servant was not menial or degrading, nor is it necossarily so to-day. Whether the position is a high or a low one depends not so much on the work done as the person for whom it is done. Miss Bacon characterires the situation of the women servants in this happy way. "The women servents in a family are in position more like selfrespecting, old-fashioned New England 'holp' than they are like the modern 'girl'".

Nothing has been said so far about the wages received by servant8. These are 10w as compared with the same in our 1. Japanese Girls and Women, p.306. 

own land. Three or four dollars a month is good wages for a man, and women, also men in the less well-to-do families, receive much less than this (at the same time they provide their own food and bedding etc). Professor Iloyd claims that menservants get usually about $\$ 15.00$ per annum besides their board and clothes, and that a joung girl gets nothing but her food and clothing and occasional presents. When a servant girl marries she looks however to her mistress to supply her trousseau, and the tie between master and servant is always recognized even after the service has closed. It is the common thing for servants in moderately well-to-do families to have worked into their garments,- particularly the outer coat, the family crest or insignia or something to show where they belong. 

HORALITY.

The question of the morality of the Japanese people is often spoken of adversely by people who cla im to be well versed in things Japanese, so it is well that we give some notice to the subject. In considering the question of morality, as with that of politeness, we must first determine what we shall consider as the basis of moral action-and we must not, I think, take for granted that our own ideals are necessarily the highest ones. In Japan filial piety and faithfulness to the Fmperor are the greaters virtues known and immoral indeed is the man or the woman whof ails in either of these. "No text in Bible raises so much prejudice here against Christianity as that which bids a man leave father and mother, and cleave to his wife. 'There! you see it', exclaims the antiChristian Japanese, pointing to the passage, 'I always said it was an immoral religion'". ${ }^{1}$ If we define as moral those

1. Things Japanese, P. 166.

$$
5-2
$$



actions that are in conformity to our own moral code, then we must admit that in Japan there is a lamentable lack of public sentiment against the things which we commonly think of as being immoral. In regard to honesty, truthfulness and such like qualities of character my own experience is that there is very little real difference between Japan and our own country. Just here it is well to consider some things which are most commonly spoken of as indicating the low moral standards prevailing amongst the Japanese people. Perhaps the first of these is the different conception as to what constitutes the highest virtue in woman. "With us, a virtuous woman--means simply one who keeps herself from personal dishonor. Chasity is the supreme virtue for a woman-.- the whole perspective is arranged with that virtue in the foreground". ${ }^{1}$ But with the Japanese "obedience and loyalty are the supreme virtues". Fmbodied in this conception is mach of the history of the Japanese people-their acceptance of the teachings of Confucius and their practice of ancestor worship. It is this conception then of what constitutes the noblest virtues that must account for much of what to us is evil in Japanese society. Many girls are either sold by their parents into lives of prostitution or voluntarily give themselves up to the same when it seems necessary in order to care for the family. The family is of more

1. Japanese Girls and Women, p. 218.

$$
s-3
$$



importance than the individual, and therefore it is noble to sacrifice one'g self in any way for the good of the whole. This accounts, I say, for much of the prostitution that we find in Japan to-day, and that there is much of it oannot be denied. Yet I question if it is much, if any, worse than in our own country. It is more open perhaps. In so much that a great major Ity of hotels and lodging-houses count it a necessary part of their business to keep one $6 r$ more such women for the accomodation of their guests, and it is considered the proper thing for a man spending the night there to have suoh a companion forthe evoning; and in some places it is counted always as a part of the bill whether taken advantage of or not. As to the prevalence of sexual. sins arong young people,-students and others, the different statements on the matter are so much at variance that it is difficult to determine what is even approximately correct. If we confine ourselves to the small centers of population I am of the opinion that in former times it has been and is largely yet much more common than in our own country.? This discussion wonld not, however, be complete without some reference to the sociel relations existing botween the sexes in Japan.

In this regard, "There is a Japanese wall as well as a Chinese wa 1 , and the former separates the young men and women

1. One who had spent many years in Japan as a physican has said that it was doubtful whether any appreciable number of Jipanese girls over sixteen years of age are virgins. Another report was to the effect that of the students who presented themselves for entrance examinations at one of the colleges at least one-half showed signs of having had venertal diseases. 

of the land". I Until five or six years of age children associate freely and even in the promary schools, during the first four years, there is very little separation, but beyond that they have separate class rooms, play separately, do not mingle. Preoly in the home, do not associate in social gatherings, in fact in almost no way do they come into intimate relations with each other. Even in their association during their early childhood, it is always the boy who is the leader and the girl who takes second place, for so she has been taught to do-this is one of the first lessons she must learn. Young men have scarcely no opportunity of associating with joung women, except it be with those with whom they should not associate, geisha (danoing girls) and it might be remarked in this is a double danger for young men, for not only is this the only opportunity they have of satisfying the social nature, but these girls are, as a usual thing, bright, well trained and capable of entertaining men in a charming way and so leading them to fall under their seductions. Even after marriage, the woman does not take partfor very little part in the social life of the home. The man entertains his friends but his wife either absents herself altogether or comes only to help in serving refreshthents etc.

Outside of the home, on the streets, at the shops, in the theatres etc. men and women mingle freely, that is women are not secluded and shut up in the home $a \mathrm{~s}$ in some other oriental countries. In their publio assemblies where women are present

1. The Japanese Bride, p. 11. Naomi Tamura.

$$
\delta-s-
$$



they do not have partition walls between them and the men as they do in Korea, even in their churches. They even go one better than we do in that regard, for not always, and in former times scarcely ever, is there a partition separating the two parts of the public bath house. I have seen, in country villages, where the police in deference to foreign sentiment, demanded a separation, a partition made by putting up a few boards with spaces of several inches between them. This brings us, however, to that other subject about which I am lead to believe there is a great deal of misconception- that of nudity in Japan. Nudity. Whether it be because the Japanese are great lovers of nature or not I do not know, but they do not look upon man, or woman, when clothed only in the garb of nature, as an object of curiosity or reproach, provided this appearance be necessiated by the ordinary affairs of life or business. The Japanese woman seems to think it nothing at all unworthy if her person be exposed, for example at the bath, or at her work in the home or by the wind blowing her gown on the street, but I will agree with many who have lived longest in Japan by saying that she would shrink as much as our most refined women in America from volumtarily exposing her person to attract attention-and here it may be remarked that Japanese women consider the evening dresses of our American women as being highly immodest, for she knows nothing, or perhaps we may say does not care to know, of that art which determines to a nicety just how much of the bust may be exposed to the admiring gaze of gentlemen friends. Neither does she array herself in those bewitching, if not disgusting, costumes which one sees at our fashionable bathing

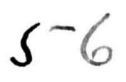



resorts. It is not at all an uncommon sight, in country villages to see children playing around at home entirely naked, or to soe a man sauntering along the street of a summer evening, $f$ after coming out of the bath, carrying his kimono and wearing a loin cloth only, or to seo people bathing in a tub out in the yard and exposed to the view of all passers by. While it is difficult for un American to see euch things without "thoughts rising in his mind" yet I am persuaded that a Japanese looks: upon such things as unmoved as we do upon the ordinary appearance of men and women on the street. It is only in villages and small country places, however, that one sees to-day nudity to any noticeable degree and even there, especially if there be any Western persons around, the police are becoming very careful and many times I have seen them require workmen to put on their clothing which they had laid side while at work. 

BLIGION.

As it is impossible to thoroly understand the life of any people without knowing something of their religion and the religious evolution thru which they have passed, so it is very difficult to account for many things in Japan without taking into account the religions found there. In Americe there has been and is more or less jet, among certain classes, a lamentable failure to vitalif associate a man's religious worship and his moral conduct. In Japan, on the other hand, a man's religion is largely made up of acts of moral conduct, and jet we must remember that morality in Japan means filial piety and loyalty. rather than personal character and regard for the rights of others, as we see them. In short to the old time Japanese, or to the ordinary villager of to-day, there is no separation between divine law and governmental law. This is strikingly borne out by the fact that in the Japanese language there is no word for sin as distinct from crime. and a man is likely to resent being called a sinner because to him that oimply means one who bfeaks the law-a oriminal-and there is amongst Japanese a much higher regard for law that among Americans. "It 1s therefore easy to understand why Shinto never had a written code of morals, and why its greatest scholars have declared that a moral code is unnecessary. In that stage of religious evolution whioh ancestor worshlp represents, there can be no distinction between teligion and ethios, nor between ethics and custom. Government and religion are the same, custom and law are identified...-assuredly the religion of Shinto needed no

$$
s-8
$$



written commandment; it wa taught everybody from childhood by precept and exemple and any person of ordinary intelligence could learn it". I The following quotation from Dr. Griffis shows well the above mentioned connection between government and religion with the Japanese. "For a little while, in 1868, the Jin Gi Kuan of Council of the Gods of Heaven and Earth, held equal authority with the Dai Jo Kuan, or Gret Council of the Government. Pretty soon the first step downward was taken, and from supreme council it was made one of the ten departments of the government. In less than a year followed another retrograde movement and the department was called a board. Finally, in 1877, the board became a bureau. Now, it is hard to tell what rank the Shinto cultus occupies in the government except as a system of guardianship over the imperial tombs, a mode of official etiquette, and as one of the acknowledged religions of the country".2 At the same time "The radical shintoist to this day believes that all palitical rights which Japanese enjoy or can enjoy are by virtue of the Mikado's grace and benevolence". 3 Instead then of calling the Japanese frreligious, as some have done, we must admit that with their daily worship at the family shrines within the house, their constant visits at their temples, shrines and ancestral tombs, their pilgrimages to sacred places, their festivals etc. they make more of their religion that do we. The day begins by rising early and washing the face and hands, ringing out the mouth and cleansing the body. Then the

1. Japan- An Interpretation, p. 112-13.

3. The Religions of Japan, p. 94. " W. E. Griffis. 

worshlper turns toward Yamato lone of the central provinces and one designation of the country), strikes the palms of his hads together twice and worships, bowing the head. Yet, "as the number of gods who possess different functions is great, it will be convenient to worship by name only the most important and to include the rest in a general petition. Those whose daily affairs are so multitudinous that they have not time to go thru the (presoribed) morning prayers, may content themselves with adoring the residence of the Fmperor, the domestic kami-dana. the splrite of their ancestors, their local patron god and the deity of their particular calling in Iife". ${ }^{1}$ Another point of difference between their concertions and ours is well brought out by the following quotation- "On more than one occasion we have heard a Japanese asked by a European traveller what his religion was; whether Budahism or Shinto, and been amused at his look of blank perplexity. He could not for the life of him make out what the inquirer was driving at. It is the established custom to present infants at the shinto family temple one month after birth. It is equally customary to be buried by the Budist parish priest. The inhabitants of each district contribute to the festivals of both religions alike, without being aware of any inconsistency". 2 In the same way the Christian missionaries find many people ready to become Christians, if they may retain their old faiths, and they look upon ChristianIty as being very intolerant when they learn they cannot.

We may say that to-day, nominally, the people of Japan are, With emall exception, adherents of three systems of teaching-

1. The Religions of Japan, p. 86. quotation from Hirata. 2. Thlongs Japanese, $p$ ! 409 . 

Shinto. Buddhism and Confucianism- with an ever growing admixture of Christianity. As has been said before however- "So far as the differences between Shinto, Buddhism and Confucianism are recogniged,...-Shinto is the cult for the living. Buddhism for the dead, and Confucianiom is the moral code. For worlaly prosperity people pray to the Shinto household idols or at the shinto shtines; for things pertaining to the dead, or to the prospect of death and the future life, they pray to the Budihist 1dols and at the Buddhist temples; for moral guidence they study the literature of Confucianism ${ }^{1}$ and Christianity.

Shinto. Shintolom may be described as a mixture of nature worship and the rorshlp of ancestors, especially of certain chiefs and heroes. It may even be called to-day, as it exists among the common people, a "bundle of miscellaneous superstitions, rather than asstem of religion," It means literally "the way of the Gods".

The history of Shintoism may be divided into three periods. Unt1l about the siath century of the Christian era it was the sole religion of Jupan, but at that time Budahism was Introduced and Shinto was overshadowed and its further growth in the way of a rellgion was stopped. Buddhiam remained dominant till about 1700, but during the perceful time of the Tokugawa Shogunate the minds of men began to turn back toward the past- and Shinto was largely revived. "Buddhism and Confucianism were sneered at, because of their foreign origin".2 The Shinto of 1700, however, and even more so that of 1900 , was not the same as that before the introduction of these

1. Japanese Buddhism, p. 30 .

2. Things Japanese, p. 421 .

$$
61
$$



other religions. It contained a large admixture of thought from these. It remains very largely true tho that the two dominating principles are to follow one's impulses and to obey the Mikado, and along with these go the worship of the First Imperial Ancestor, by all the people, the worship of the patron god of the looality and the worship of the family ancestors by each house? hold. This last forms a very consplouous part of the worshtp. And, "It should be recognized", says Hearn, "that no religion is more sincere, no faith more touching than this domestic worship, which regards the dead as continuing to form a part of the household life, and needing still the affection and the respeot of their chilaren and kindred". 1 As to the thought back of this worship, a Japanese writer on "Ancestor Worah ip" says: "We celebrate the anniversary of our ancestors, pay visits to their graves, offer flowers, food and drink, burn incense, and bow before their tombs entirely from a feeling of love and respect for their memory, and no question of 'dread' enters. our minds in doing so".2 Some such a prajer as the following is offered to them. "for aid received, by day and by night, accept, August Ones, our reverential gratitude". 3

Buddhism which was introduced into the Empire from Korea in the sixth century has been the most powerful reifigis force in the nation. Tho the ideas and practices that have entered into the history of Japanese Buddhism constitute $a$ grotesque compound, jet certain elements have run thru all the history of the faith. These may be named as transmigration;

1. Japan-An Interpretation, p. 52 .

2. Ancest or Worship, p. 7. Nobushige Nozum1.

3. Japan- An Interpretation, p. 521 .

$$
62
$$



pantheiam- "men are phenomena, links in the chain of transmigration. The gods represent forces, or conditions, or principles, rather than distinct personal beings"; and religious contemplation- "a mystic sinking of the individual mind into the great A11, or rather-..- the great Nothing". These and others such as pessimisin, polytheism, and idolatry, are found in Japanese Buddhism. The "Budahist dead are not called gods, hut Buddhaswhich term expresses a pious hope rather than a faith. The belief is that they are on their way to some higher state of existence; and that they should not be invoked or worshipped after the manner of Shinto gods; prayer should be said for them, not, as a rule, to them". 1 "Popular Budahism (however) worships every man, dead or living, who has attained Nirvana".2

As to the relation that Buddhism recognizes between its own deities and those of the Shinto pantheon, Kobo Daiishi, the great teacher who promulgated Buddhism in Japan, said; "AII the Shinto deities are ayatars or incarnations of Budaha. They were manifestations to the Japanese before Gautama had become the enlightened one-...... Furthermore, provision was made for the future gods and deified holy ones". 3

The Buddhist canon has never been translated into Japanese. The priests use the Chinese, if they use any, and the common people use none.

In outward form there are many points of resemblance between Buddhism and Roman Catholicism. In the capitol resides

1. Japan-An Interpretation, p. 55.

2. The Evolution of the Japanese,- Sidney I. Gulick.

3. The Religions of Japan, p. 201. 

the high priest, having virtually the same prerogatives as the Pope at Rome. The clergy live together in monasteries and correspond well with the monks and friars of Romanism. There are stately temples and shrines "upon every high hill and under every green tree". There are flowers on the altar, candles, incense, the shaven heads of the priests, the rosaries, the Images and the processions.

In Japan there are many sects of Buddhists, a few of which are the following:- the Nichiren Sect which was founded in 1282. It includes within its pantheon all the prescribed Budahas, and has canonized pretty nearly all the saints, righteous men and favorite heroes known in Japan. It is the most idolatrous of all. The Jodo Shu or Sect of Fure Land, the land where Amida lives. All that is necessary for salvation, according to this sect, is the continual repetition of the prayer to Amida, which is usually in this form- "Namu Amida Butsu" (Hail, Amida Buddha) and is repeated hundreds of times a day. The Shin Shu or True Sect lays emphasis on salvation wholly thru the merits of another. It has been called Protestant Budahism. It opposes celibacy and asceticism, does not restrict diet, worships only one Buddha and preaches salvation by faith.

igious Iife of the But let us try to sketch very briefly the religious lage. life of an ordinary village. Probably the largest building in the village will be the Buddhist temple and there may be more

$$
64
$$



than one.

The inside of a Budaist temple.

The Shinto shrine will be a more modest affair and very likely off to one side under some large, centuries old, trees or perhape on the mountain side or some high place.
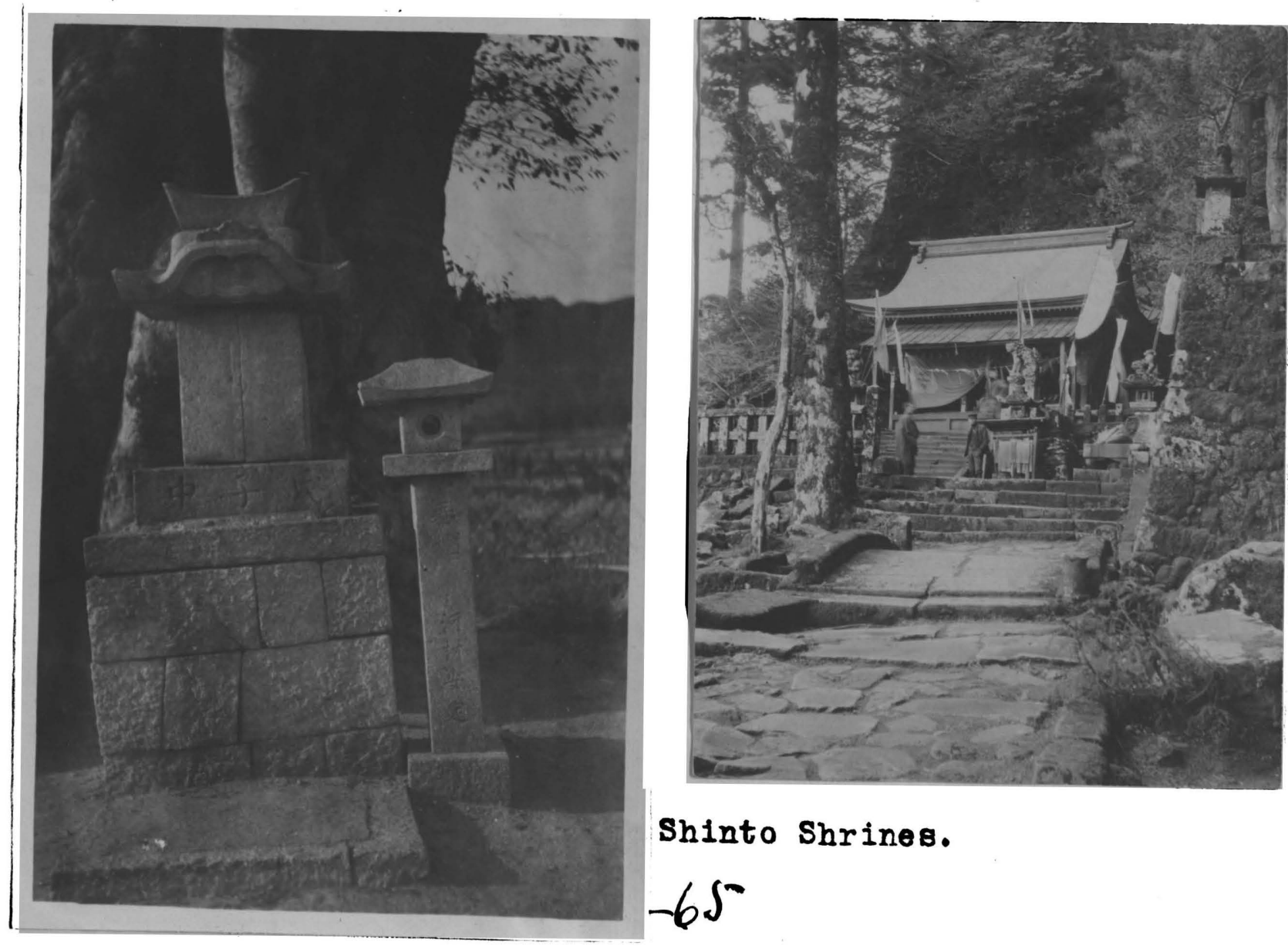

Shinto Shrines.

$-65$ 

These temples and shrines do not compare exactly to our churches. They are the places where the images and objects of worship are kept and where the people go at stated times, for festivals and also to observe the anniversaries in connection with the family, to worship and to burn incense. But seldom do they gather in congregations as we are accustomed to do to hear preaching. In fact tyere is little cause for preaching, as few converts to the faith are made in this way, for children as they grow up carry on as a matter of course the religion of the family. In enumerating the strength of Budahism or Shintoism the families only are counted and all within the family are considered as adherents.

The Shinto shrine is a double structure, both portions of which are very small. The smaller part is in the rear and is completely enclosed and locked. This is the holy of hories and here the sacred emblems are kept. None but the "god-keeper" may enter there. The eront part is larger and is open usually at the eront. The worshiper does not enter but stops at the entrance, rings the large "bell" which is a hollow brass structure with something in it to rattle and is rung by striking against it the large cloth rope which hangs by it, claps his hands and bows his head in a few moments of prayer. "It certainly is surprising to find neither graven image nor idolatrous worship in pure Shinto shrines". 1

1. Religions of Miseion Fields, p. 29. 

Part of the religious life of all Japanese is connected with the many festivals which they hold at their temples and shrines. One of the most important of these is $\underline{0}$ Bon- the All Souls day of Japan. It is the popular belief that at this ocoasion, which is the fifteenth day of the seventh month, according to the lunar calendar, the spiritg of the dead are allowed to escape from hell and visit the scenes of their earthly life. In consequence as a preparation for this event the gravejards are all cleaned and the graves trimmed with flowers arranged in Ittle bamboo stunds; the household shrines are adorned with flowers and leafy branches; feat are prepared for the returning spirits which must be hongry and thirsty, and lanterns are lit and hung outside the door to guide the wandering spirits. In the temples the priest are busy reciting the Buddhist services for the dead, and many come to worship. The head manof the village invites all the heade of families to share his hospitality. Visits of congratulation are exdhanged, everybody takes a hollday and all have an enfojable time. Not only are the temple services thronged, but each family invites its parish priest to a special service before the home altar. In connection with this festivel there is a dance at night, called Bon-Odorl. This is not held in verg high repute by the better class of people and is rerely seen except in country places.

The Matsuri or festival of the Shinto deity of the village probable comes next. Here again the heads of families assemble, this time at the Shinto shrine, sud the white robed priests conduct a simple service, accompanied by music, if anj- 

thing in Japan may be so named. The matsuri is almost always accompanied with many amusements and is what we should term the village pionic, for there are all kinds of little booths for selling toys and sweetmeats, and for juglers and shows etc. Besides these there might be mentioned many festivals, such as the girls' doll day on the 3rd day of the third month and the boys' day, on the 5th day of the fifth month- when will be seen the paper fish flying from poles at every house.

ligion in le home.

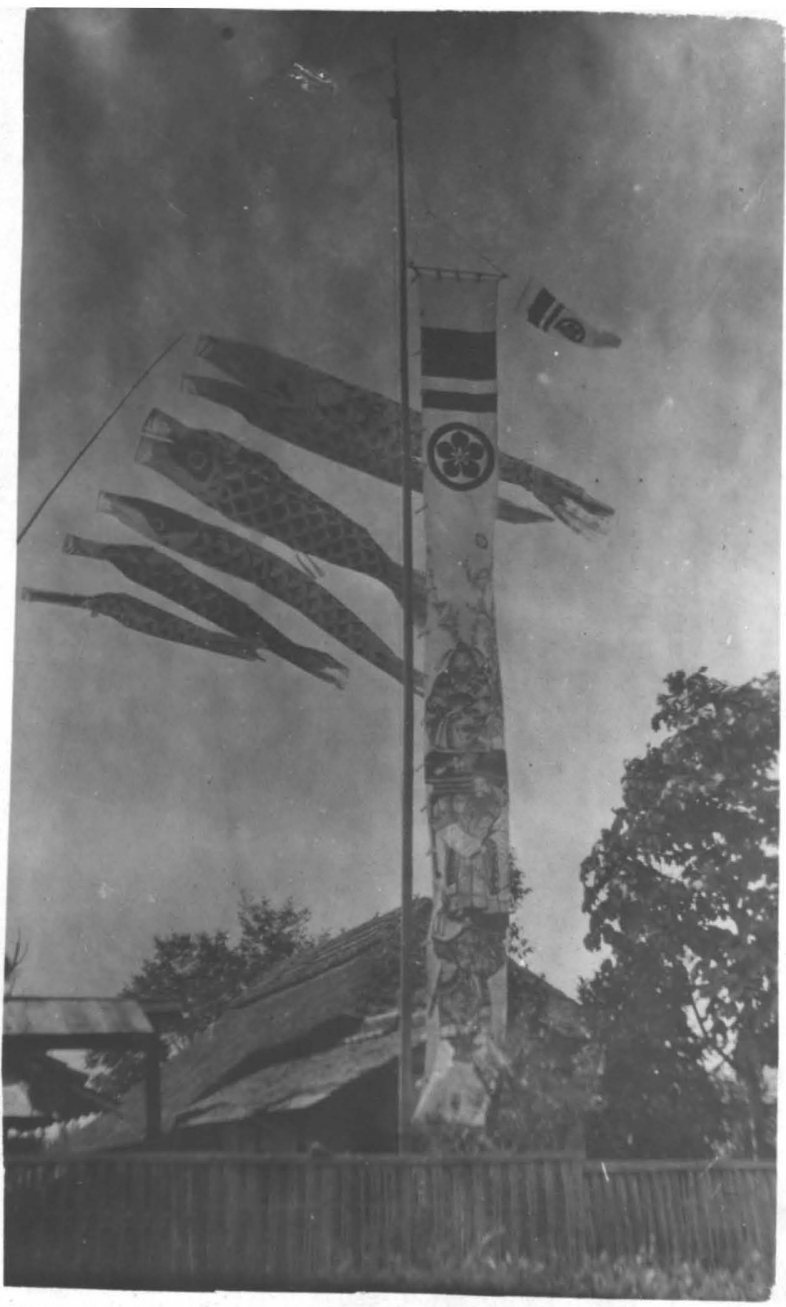

"Every well-ordered Japanese home of the old-fashioned kind," say Miss Bacon, "has its little shrine, which is the center of the religious life of the house. If the household is 

of the shinto faith, this shrine is called the Kami-dane, or god shele, and contains the symbols of the gods, gohei, in vases, receptacles forfood and drink, and a primitive lamp,- only a saucer of bil in which a bit of pith serves for a wick. Daily offerings must be made before this shrine, and reverence paid by the clapping of hands; while on feast days special offerings and invocations are required. In Buddhist families, the Butsudan or Buddha shelf, takes the place of the Kami-dana. (In many oases however both religions will be observed, so that both Kami-dana and Butsudan will be found and the worship is slightly more complicated. ) Greater variety of food is offered, and the simple clapping of the hands and bowing of the head that is the form of prayer in the shinto religion is replaced by the burning of incense and actual verbal invocation to Buddha. These religious ceremonies must be attended ${ }_{\Lambda}$ by the mother or wife. She it is who sets the rice and wine before the ancestral tablets, who lights the little lamp each night and who sees that on each feast day and anniversary season the proper food is prepared and set out for the household gods"! On the Kami-dana is usualiy a all shinto shrine containing tablete bearing the names of gods and various holy texts or charms, often written promises in the name of sore god to proteot the worshiper. Very rarely are images found on the Kamidana hut often there will be the paper gohei or "prayers" as they are commonly called which are said to represent the ancient

1. Japanese Girls and Women, p. 328. 

offeringe of cloth otc. made to the gols, and the ghimenatia, or etraw rope will be stretched in front of the shrine or above it. The Kami-dang is usualiy put at the height of six or seven feet, at one side of the room or often in a special place in the wall where a kind of closet 18 made for it. It is commonly a plain white wooden shelf. "Before the sacred objects on the shelf are set two quaintly shaped jars for the offerings of sake: two small vases, to contain sprays of the sacred plant sakaki. or offerings of flowers; and a small lamp shaped like a tiny saucer, where a wick of rush-pith floats in rape seed ofl. - ... The little lamp may not be lighted every evening in all houses, since there are families too poor to afford even this infinitesimal nightly expenditure of oil. But upon the first, fifteenth and twenty-eighth of each month the light is always kindled; for these are the Shinto holidays of obligation, when offerings muat be made to the gods, and when all uflko or parishioners of a Shinto temple are supposed to visit their Ufigami". " On the Butsudan, or Buddhist god shelf are the lhai or family ancestral tablets which are often about $2 \times 6$ inches in sire and may be made of wood or metal and may bary in price from a few sen to many dollars. On each is written posthumous name of the individual whom it represents, and on the reverse the real name and date of birth and death. On the Butsudan may also be one or more images of gods, particularly will there be one of the seven gods of luck, without which no nousehold could well exist. The first duty in the morning is to set before these tablets on the Butgudan oups of tea, made with the first hot water prepared. Daily offerings of boiled rice are also made and incense is burn-

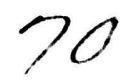



$\theta d$, and prajers are said before the iha1. A lamp is also lighted on the shelf in the evening and often flint and sted instead of matches are used in lighting it.

The temple grounds in the village are usually play grounds for the childr. As a baby he is taken to the shrine at about one month old and put under the protection of the god and his name is there recorded. Thereafter he is taken there on special. birthays, on all festival days, and on many occasions he find there toys, sweetmeats, fun etc. Altogether he grows up and Iive in intimate relations with his places of worship.

IPERSTITIOIS.

Very closely related to the religious life of the people, if not directly a part of it, are their superstitions, and the Japanese may in justico be called a very superstitious people. Practically every Individual wears his amulet of some kind. On nearly all houses, especially among the lower classes, w1Il be seen one or more papers with inscriptions ard generally pictures, the fox god for instance, on the sacred dog Mitoumine who is esteemed a powerful protector against robbers, posted on the outside of the house near the door, as a protection from evil spirits. To secure such charms is alwajs one object of the pilgrimages to sacred mountains and famous shrines. Bosides these paper charms there are various others, pieces of wood from temples that have been torn down, food that has been offered to gods at famous places etc. A man in Tokyo made a living for nearly fifty jears collecting dust from the temple

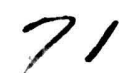



floor and selling it to keep Eway evil. This is perhaps only a sample of what hundreds of others are doing. Mr. Griffis says, "So far as I could judge, in Japan, the majority of the lower classes believe implicitly the household superstitions current among them". 1 The following are some of those superstitions:1. Never sweep the house immediately after a member of the family has set out on a journey. This would sweep away his lukk. 2. Do not wear purple at a weding for purple soon fades and so the marriage ties might soon be broken. 2. To get rid of a caller who has remained too long, go to the kitchen, turn the broom upside down, put a towel on it and fan it. 4. If small pox is in the community, a notioe that the children of the family are absent posted on the door will keep it away. 5. A corpse is:always placed with the head to the North, consequently one should never sleep with the head in that direction. 6. If a woman steps over an egg shell she will go mad; if over a razor, it will become dull; if ofer a whetstone, it will be broken. 7. Foison is supposed to fall from the sky during an eclipse of the sun, so all wells are carefully covered at that time. 8. The soul is supposed to be a round, black thing and is absent from the body during sleep, so there is danger in waking a person suddenly for the soul may not have time to get back and the person will die. 9. A girl who has been deserted by her lover often makes a straw image of him and goes to the temple grounds at 2:00 A.M. and nails this image to a large tree, and continues this nightly till he sickens and dies. 10. During a thunder

1. The Mikado's Empire, p. 466. 

storm, people often get under a mosquito net for there the thunder animal cannot get at them. The effects of lightning are caused by the claws of this animal. 11. There are many lucky days and no important undertaking will be begun except it has first been determined what day will be lucky. 12. There are superstitions with regard to the power of the priest to bring punishment to any one, as the following clipping from the"Japan Times" will illustrate. "At Shinokobu, a small village in Soshu, consisting of only seventy houses, several cases of robbery have lately occurred to the great alarm of the viliagers. A di] igent search instituted by them for the offender proved an utter fuilure. The community held a mass meeting and unanimously agreed up on the resolution of cursing the robber to death. A virtuous priest of the locality was therefore applied to for the purpose. He, however, declined to curse the robber to death, an act too cruel for a holy man like him to resort to, but promised that he would paralize the robber by his powerful wrayer so as to disable him and lead him to repentance. Thus the priest commenced his incantations. But behold, the robber continued his subtle operations to the indignation of the entire community. The priest has been dondemned as a worthless fellow, and the tillagers took upon themselves the task of repairing every day to the village temple by twos and three to offer horrible prayers by which the robber is doomed to an early and fearful death" 13. Nany are the superstitions connected with foxes. There are demon foxes that have the power to take diabolical possession of 

a person, to deceive by enchantment. They may likewise quarter themselves, with a vast train with them, in the house and eat up everything. They may assume any form- the favorite form being that of a beautiful woman. It is not perhaps surprising therefore that one should find all over Japan fox shrines where such demons are placated by worship and offerings. Besides these demon foxes there are however good foxes and these are supposed to bring health and wealth. 14. The ceremony called "Setsubun" is observed in early spring time. It consists in casting out the devils from the house by a professional and then putting up small charms over all entrances to prevent their entrance again- spring house cleaning indeed. 15. People buy paper images of persons at the temple- one for each member of the family-take them home and rub on the body and return to the temple to be burned. Thus may all physical misfortunes be averted. 



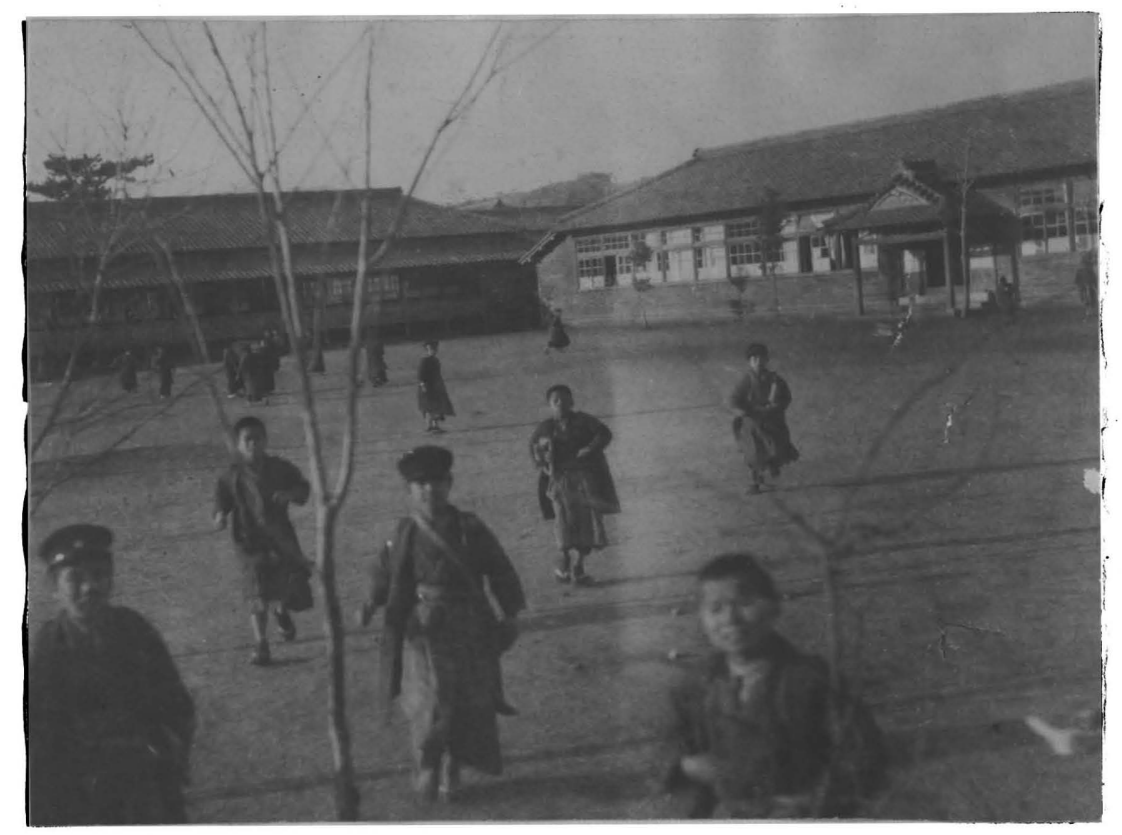

DUCA TION.

Fducation in Japan dates from about 300 A.D., when ocholars came from Ohina and Kores to teach Chinese learning and ideographs at the Imperial court. At this early date, however, there was no attempt at a diffusion of. knowledge among all classes, rather the object was to prepare special men for service in the Government. For this purpose a kind of University was established at the capital city, in which the chief subject of study was the Chinese Classics.

Ieyasu, the founder of the Tokugawa dynasty of shoguns (1603-1858), was a liberal patron of learning and did much to encourage the organization of sohools and libraries. "He established at his oapital, in Yedo (now Tokyo), a college which 

attained great celebrity, and was attended by more than 3000 pupils". I Several of the daimyo (hereditary lords) established like schools in their own provinces. These schools, however, were solely for the samurai (military retainers) and had nothing to do with the common people. The only education they could obtain was in private schools or from private teachers, and jet it is olaimed that under these circumstances the majority of the merchants, artisans and farmers were able to read and write the simple native symbols and to cast up their accounts on the counting-frame (soroban).

"The daily routine of a Japanese school such as above described would be about as follows: At the opening the students all assembled, say to the number of three or four hundred, in a large assembly roon. Here a professor gave a lecture to the whole body of students on some passage selected from one of the Chinese classics. The lecture consisted of explanations and comments on the selected passages and exhortations to the young men to conduct their lives accordingly. Fach student was required to have a book in his hand, and to follow the citations and comments of the professor.

After this general lecture the students retired to separate class rooms, and under subordinate teachers read over the works enumerated in the text-books. They were required to explain the meaning and to answer questions to their teachers. On certain days, also, they drew lots to discourse upon some previously-assigned passage -....... Following these exercises were others teaching them composition, and giving them

7. Japanese Education (1878) p. 11

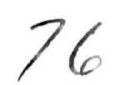



practice in the art of writing. Official letter-writing was an object of special training, and was carried on through many years. In a country where rank and etiquette, and proper observance of official forms, were deemed of the last importance, this branch of education was necessarily one not to be neglected. The latter part of the day was spent in physical exercises. As these schools were for the benefit of the military class, the students were trained in martial exercises, such as shooting with the bow and arrow, throwing the lance, running, riding on horse-back, and sword exercise....... The professors and teachers were held in the greatest reverence, and it was deemed the greatest offense for the scholars to show their impatience or lack of interest by yawning or lounging or moving their positions. Perhaps to this early severe training, carried on through many generations, are due that wonderful imperturbability of temper and that courtesy of manner which characterizes the higher classes of Japan." 1 It must be admitted, however, that these schools were not held in very high repute by the samurai. In fact learning was "considered a sign of physical disability and therefore a thing suitable only to weaklings and effeminate courtiers at Kyoto whose delicate health did not allow them to attend to the noble art and practice of the samurai. So it has been said that the se schools existed probably more for decency's sake than for practical utility.

1. Ibid, p. 15 

It was not till after the establishment of the present Meij1 Government, in 1868, that education in any modern sense was introduced into Japan. It is interesting to note here that the system as it exists to-day was largely modeled after the American system. Dr. David Murray, an American, was adviser to the minister of education from 1875 to 1897 and was largely instrumental in establishing the public school system.

The Department of Education was established in 1871 and consists of the Minister of State for education; a Viceminister, Superintendents, Bureaus, Inspectors, Examiners, etc. The department superintends the educational affairs of the country and maintain institutions essential for the state. AlI matters relative to the establighment, abolition or re-organization of schools, as well as many other questions must be rassed upon by the department. "In a similar way each local office (prefectural, district or municipal) superintends the educational affairs in its own jurisdiction and maintains at its own expense the schools required in its om territory."

The following tuble shows the number and kinds of schools in the whole country, according to the statistics of 1905.

Flementary

l"Idale School

High School

Universities Ordinary Iormal

High Normal Girls" High

Deaf, Dumb and $B l$ ind Speoial

Technical

Others

Totals

\begin{tabular}{crrr} 
Government & Public & Private & Total \\
2 & 26836 & 300 & 27138 \\
1 & 228 & 40 & 269 \\
8 & & & 8 \\
2 & & & 2 \\
3 & 61 & & 61 \\
1 & 82 & 8 & 31 \\
1 & 81 & 18 & 90 \\
8 & 3 & 28 & 39 \\
9 & 1508 & 80 & 1597 \\
8 & 678 & 1308 & 1994 \\
\hline & & & \\
43 & 29397 & 1782 & 31272
\end{tabular}



If we take the Elementary school, the Middle school, the High school and the University as representing the system of literary education in Japan, it will be of interest, I think, to compare this system with our own, in point of the time necessary to complete the course from first to last.

Amerio8.

Elementary, 7 or 8 years

High School, 4 years.

College or University, 4 years.

Totals 15 or 16 years.

Japan.

Elementary, 6 or 8 years.

Middle School, 5 years.

High School, 3 years.

University, 3 years.

Totals 17 or 19 years.

This fact must be noted, that a student is not eligible to enter the Univergity until he has had his college (High School) course. This being true, the full course is longer for the Japancse student than for the American, but we must take some further facts into consideration. While in Japan the number of Midale Schoole, High Schoole, and Universities, is 279, in America the number of High Schools, Colleges and Universities is 9,822. And again, taking the returns of 1904 as orr basis, while the yopulation In America was 80,000,000 and that of Japan 50,000,000, in round numiers, yet the number of students in the various schools shows a far greater difference, as the following table will show:

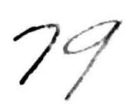



America.

Elomentary

High

Colleges and Univer-

sities

135,000

Japan

Elementery

Middle

Colleges and Univert
$17,019,259$

876,050

$$
\text { sities } \quad 9,617
$$

Each community, city, viligage or rural, of whatever size, must maintain a sufficient number of elementary schools for all the chilaren of schocl age in its jurisiction. In ease, however, a small village is unable to support a school alone it mag join ${ }_{\Lambda}^{\text {with }}$ neighboring village in maintaining one.

The elementary school is divided into two parts, called respectively the shogakio, or primary, and the kotoshogako, or grammar school. The primary grade consists of four years and the grammar grade of two or four-that is, a four years course is given but the student has the privilege of entering the middle school after finishing two years. The curriculum of the elementary school includes reading, arithmetic, history, geography, moralo, drawing, singing and gymnastics. And from the lowest schools up some form of military training is given. Students enter the elementary echool at the age of six tho in many communities kindergartens are established for jounger children. The period of comrulcory s.ttendance is now six years, and during this

$$
\text { Sくク }
$$



period, theoretioaliy the sohools are free, tho as a metter of fact in many places a small fee is charged, diredty or indirectly In the elementary schools boys and girls attend together tho often in the gramar grade they have serarate roomo or even separate bullaings. Above the elementary schools, however, there is no co-education in Japan.

Corporal punishment is not allowed in any school in Japan, jet I am of the opinion that the discipline is, on the whole, much better than it is in our own schools. True there exists, especially in the country districts, much of the old Oriental respect and reverence for the teacher, and at the same time obedience to superiors is one of the fundamental characteristios of Japanese character.

Instead of having a board of directors, as we have in the United Stater, Japanese schools are in charge of a single director who is at the same time superintendent. He is responsible to the educational authorities of the municipality, or prefecture, acoording to the grade of the school, but he has practically the full management of the school in his own hands. He appoints and dismisses teachers, tho such acticn must be sanctioned by the authorities above him.

There are three kinds of teachers in the public schools of Japan as regards license to teach. There are first the regular licensed teachers who may teach any subject in the regular course, next are the special teachers, who may teach only certain subjects prescribed in their license, and lastly there are the assistants. There are two kinds of licenses, as regards 

territorial limits; the national and prefectural. The former, however, are granted only to distinguished teachers who have taught a number of years or to graduates of the high normal schools after they have taught as much as three years. "There is a fixed schedule of salary for primary teachers." This is, for the regular licensed teachers, from $\$ 5.00$ to $\$ 37.50$ per month; for the teachers with special license from $\$ 4.00$ to $\$ 20.00$; for assistant teachers from 3.00 to $\$ 10.00$.

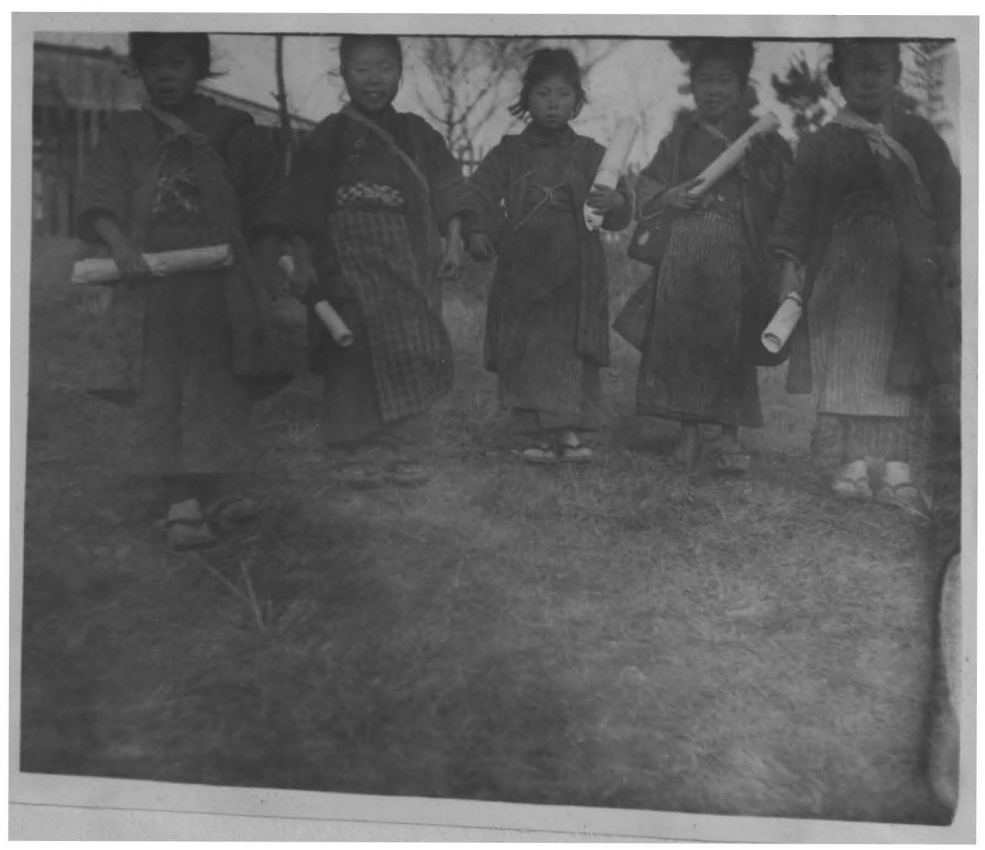



The revenue comes from subsidies and grants from national, prefectural and county (gun) treasuries for educational and industrial purposes and for public works; from taxes; from fees, such as fees for the use of public roads, bridges etc. and for the services of public officials; from fines; from quasiprivate income; and from miscellaneous income and under this head would come grants from the mperor, income from property sold ete The term quast-private income needs to be explained. Alarge number of villages, as well as many towns and all cities, have, as the possession of the village as a wole, capital in the form of real estate, money, chattels, securities etc. wich cannot be used excert in times of great distress caused by fires, earthquakes, storrs, floods etc. The interest from this cailtal, however, is used in defraying the current experses of tre community and this often amounts to considerable sum. In addition to the interet from this productive canital local communities often receive gift or donations from private sources, usually for education, charity or pub?ic works. No taxes for local expenses can be levied unlese the interest from local capital plus donations received be insufficient to meet all needs. If taxes are levied they come under about eight or ten different classes:a. Surtax on the national tax- ${ }^{1}$ the maximum being one-serenth of

1. Iund tax stood at $2.5 \%$ of assessed raluation till about 19 1895, when it was for a period of five years, as a postbellum measure, following the Chine-Japan war, raised to 3.3\%. Th is I understand has again been increased since the Russo-Japan war. The old formila used for determining the talue of the land was as follows:(Value of gross pro- duce $^{2}$ (value of seedst fer-) capital Rate of national and + prevailing rate of of land (local taxation $)+($ interest usualis 6\%) per unit. 83 

this tax; b. Surtax on national income tax; c. Surtax on national business tax-, the maximum being one-half of national tax; d. Sur tax on indirect national taxes; e. Surtax on prefectural house tax; f. Surtax on prefectural business tax; g. Special tax. "Under the name 'special tax'. there are many varieties of an independent character. Any of the cities, town and villages, as they think necessary, may select any object and impose any rate of taxation on it within the community. It mnat he approved by the Ministers of Home and Finance departments" I

In some communities tax in the form of labor or of commodities may still be occasionally met with, since to the people this seems less burdensome than a money tax. Such tax is generally used to construct roads, parks, schools, hospitals etc.

In connection with the expenditure of the public money of the village, it is interesting to note that the chief official must make out a budget and obtain the approval of the village assembly for the same at least two months before the beginning of the fiscal year; and the payment of expenditures unanticipated and those in excess of the budget estimate, and the transfer of appropriations from one purpose to another, are not allowed, unless approvel is given by the assembly".2

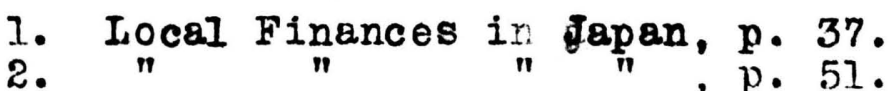





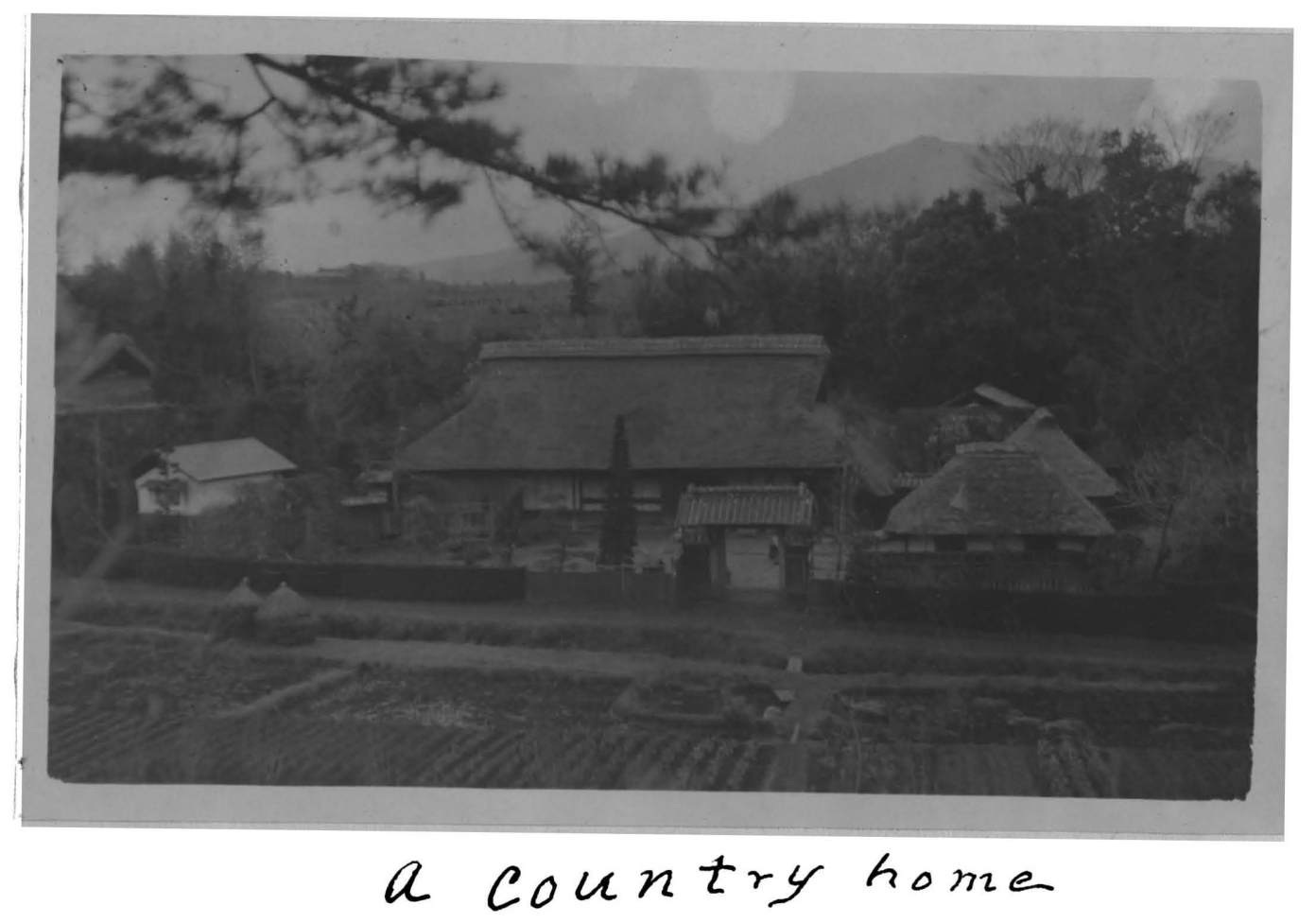

\section{INUUSTRIFS.}

1. Agriculture.

Japan is to-day and has always been a distinctively agricultural country, a majority of the people being so engaged, for "till recently the Japanese had neither manufactures nor foreign commerce, neither have they yet any flocks of sheep and goats, any droves of geese, turkeys, or pigs. Even cattle are comparatively scarce and neither their flesh nor their milk is in general use, beef being still regarded as a luxury, and milk rather as a medicine than a food. The pasture, meadow and the farmyard are alike lacking. Here, far more than in the West, 

agrioulture in 1 ts narrow sense has been all in all, forming the basis on mich the whole social fabric resta".?

Peasants.

And this despite the fact that only about twelve or fifeen percent of the land is arable, and that only about one half of the fairly fertile arable land is under cultivation and that even the cultivated portion is not highly fertile by nature. But tho the amount of land is smell it is thoroly cultivated, and tbo it is not naturally fertile "it is made so by oubsoil working,

1. Things Japanere, p. 79.

$$
86
$$



by minutely careful weeding, by manure judiciously and laboriously applied, by terracing, and by an elaborate system of irrigation", 1 so that, as a usual thing, it grows continually richer with oultivation.

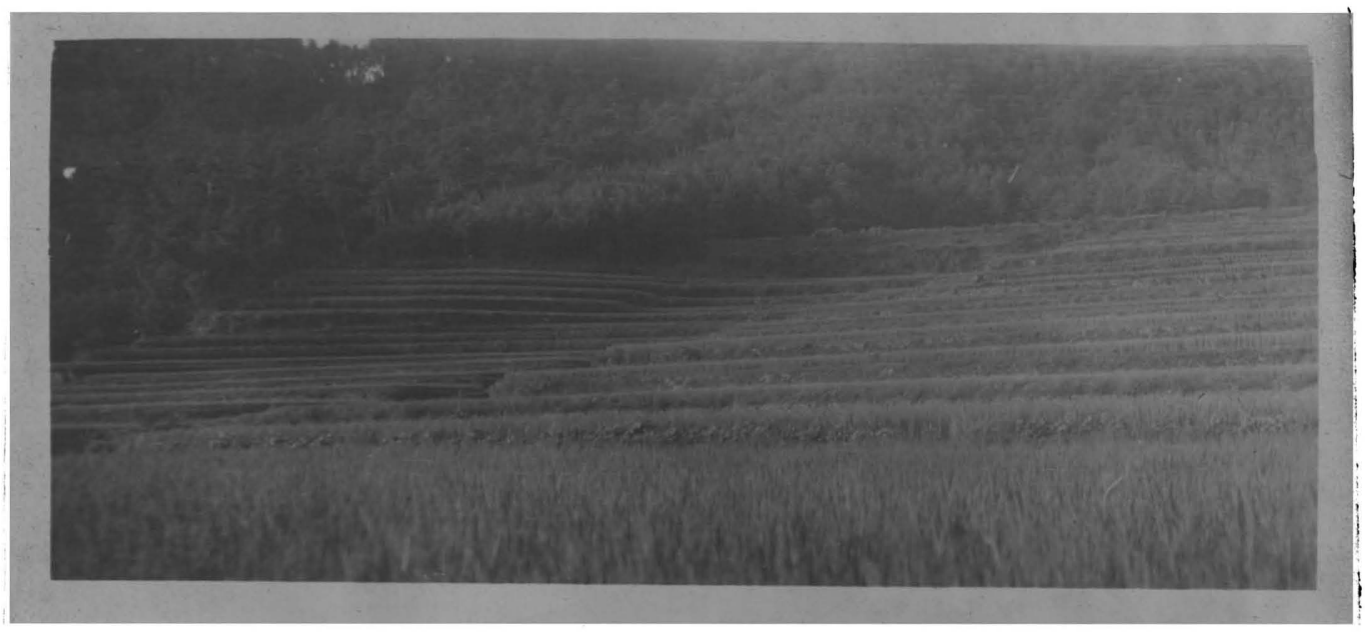

Fields terraced half way up the mountain.

The farmer understands that the soil must get back in fertilizer what is taken from it by crops. Of the fertilizers one the commonest is "night-soil". This, as well as many of the other fertilizers, is put directly on the growing plant instead of being scattered booad cast over the ground:

Applying night soil.

1. Things Japarese, p. 19. 

The further list of fertilizers includes anything and everything such as composts, fish guano, oil cakes from seeds of oil bearing plants, refuse from silk work culture, all kinds of vegetable material-straw, grass, leaves etc., water and mud from canals and swamp, ashes, lime eto. Mr. Rein gives a long and exact account of all manures and their methods of handling, particularly that of human excrements. 1

According to the Year Book for 1905 the land under cultivation is about $16,000,000$ acres. Of this amount $7,000,000$ are paddy fields, the remainder being so situated that it can not be flooded is called upland and is sown to wheat. barley, millet etc. Of the paddy fields about $30 \%$ admit of a second crop after the rice is harvested, but the other 70\% lies idle during the winter and is usually covered most of the time with water. This second crop is usually wheat, mpe or genge (a kind of clovert. Nost of the upland fields adm:t of a second, and sometimes a third crop. And here the second crop is commonly sown between the roves of the first orop long before it is harvested. And this brings us to the interesting subject of the methods of farming in use In Japan.

By far the greater amount of labor in the fielde is done with the hoe- in fact the "hoe industry"would characterise

1. Industries of Japan, pp 27-29: J. J. Rein. 

Japanese farming.

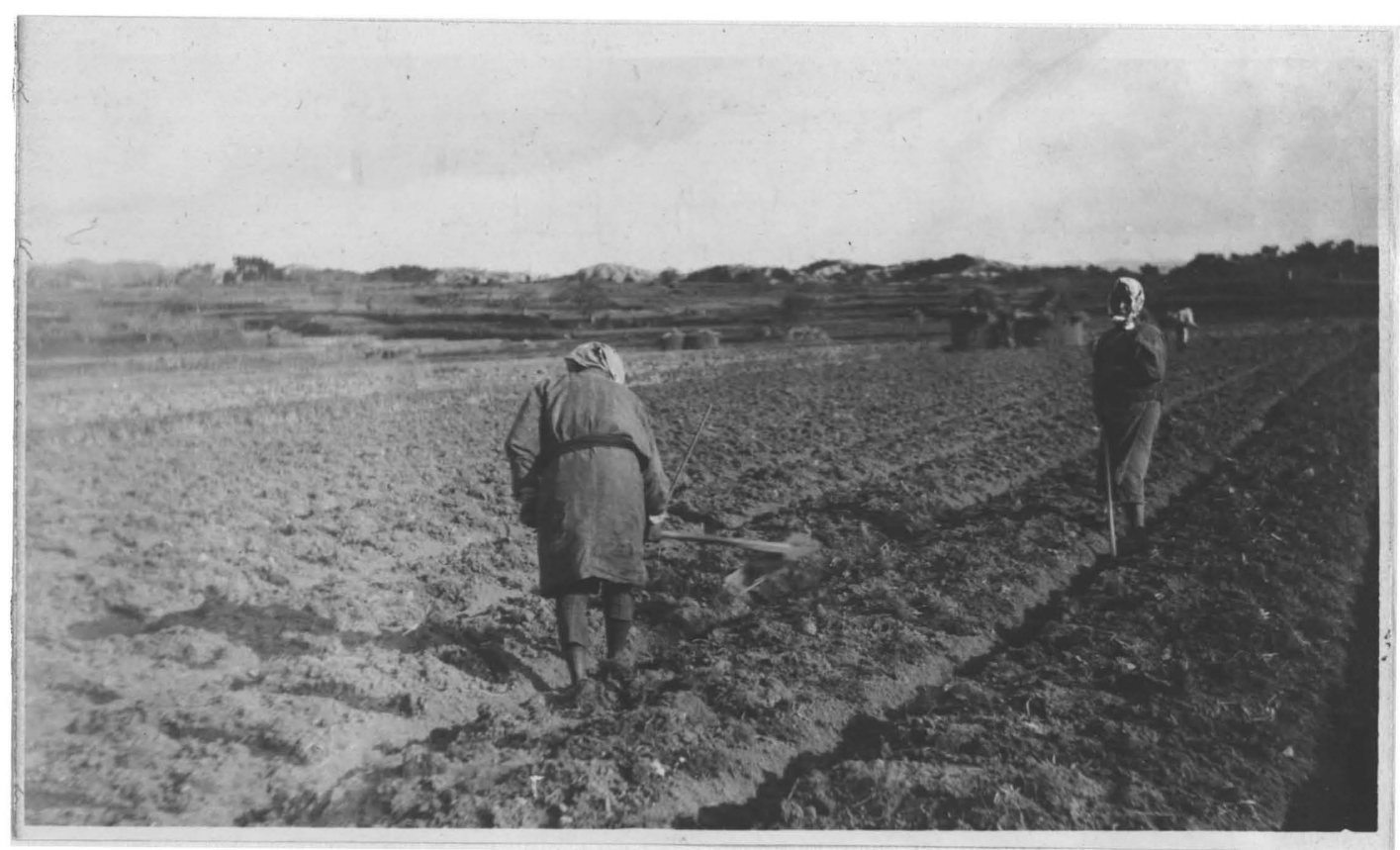

Preparing upland for wheat.

The peasant farmer that has a horse or a cow with which to break up his field is rather the exception than the rule.

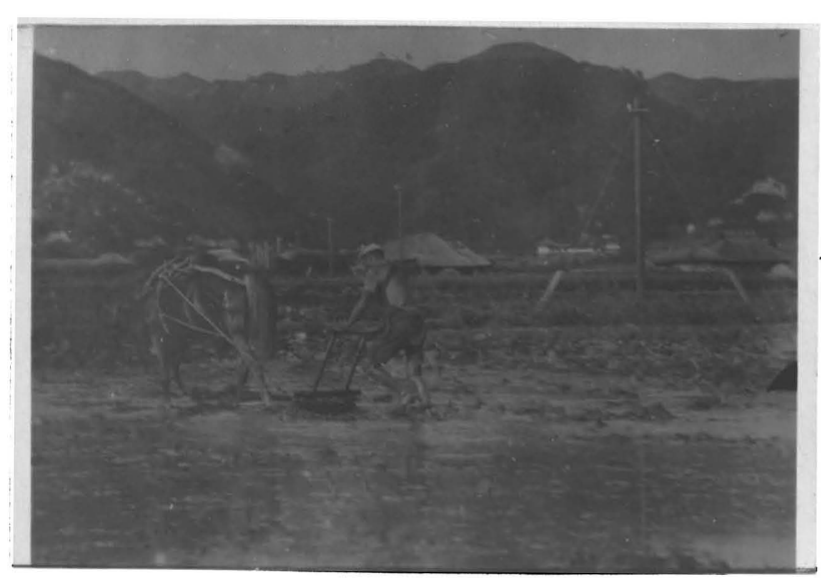

In the paddy field.

Even if he have such help his plow, differing little from that of Igypt in the time of Pharaoh, is a rude affair, cften consisting of little more than a branch of a tree shaped by nature so 

as to meet the need, with an iron shovel on the point, with no arrangment for turning the ground and no means of plowing shallow or deep at will. With this implement little more than scratching can be done, so that all deep working of the soil is done with the hoe. The accompanjing illustrations show something of the plow, the ordinary way of getting it to the field, and the stylo of harness neied.
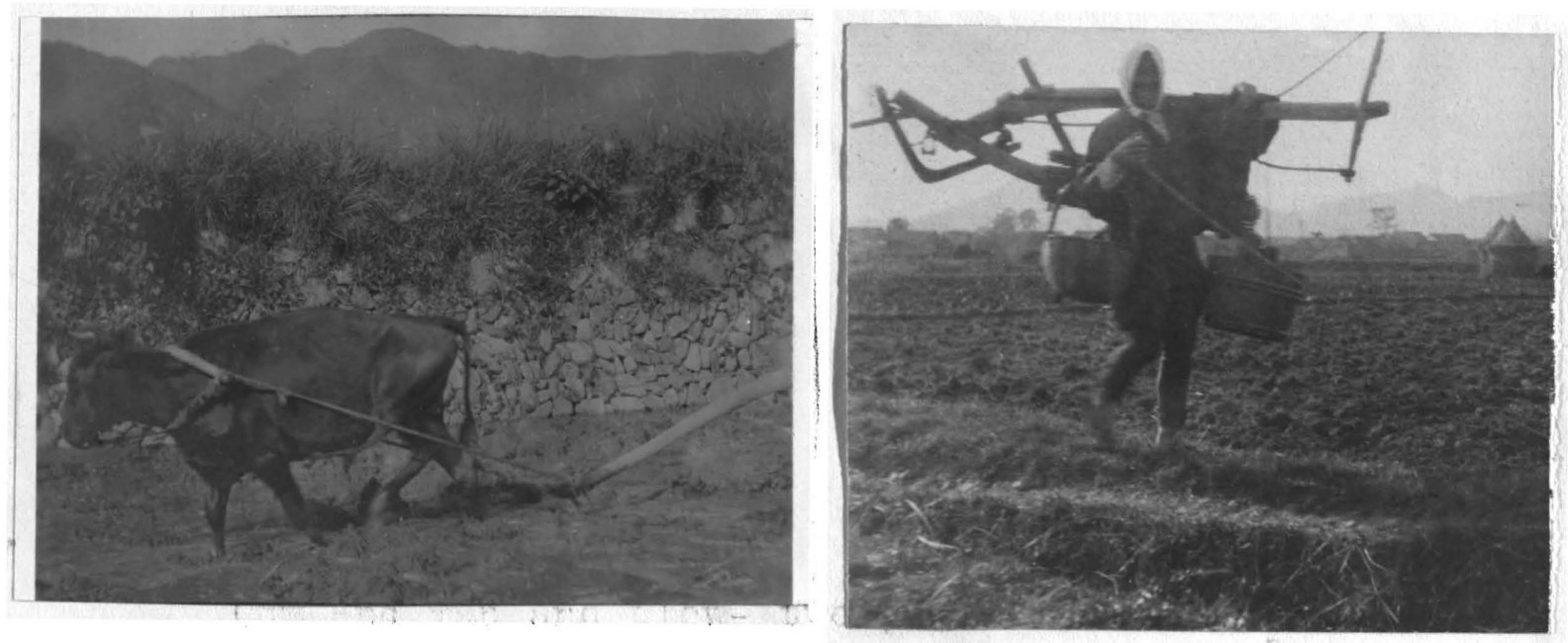

Owing to the inadequacy of the farmers' tools and to the fact that usually most, if not all the work must be done standing in water and mud almost knee deep the handing of the rice crop is an arduous task, beginning early in the spring when a small portion of the field is worked up very carefully into a soft mud on which rice seeds are sown-this 1 s the seed bed and the plants are allowed to grow here till they are eight to ten incher high before they are tkken up, usually about June, and planted in rows about oneand one-half feet a part each way on the field which has in the mean time been prepared much as the seed bed was until it consists of a soft mud from six to twelve inches deep. The rork of tramsplanting is almost always done by women, working usually from three or four to ten or thrello together standing in a row across the field, about knee deepin 

mud; each holds a handful of plants and quickly and deftly transfers them to the soil with one movement- one thrust into the mud, as the accompanying lllustration shows.

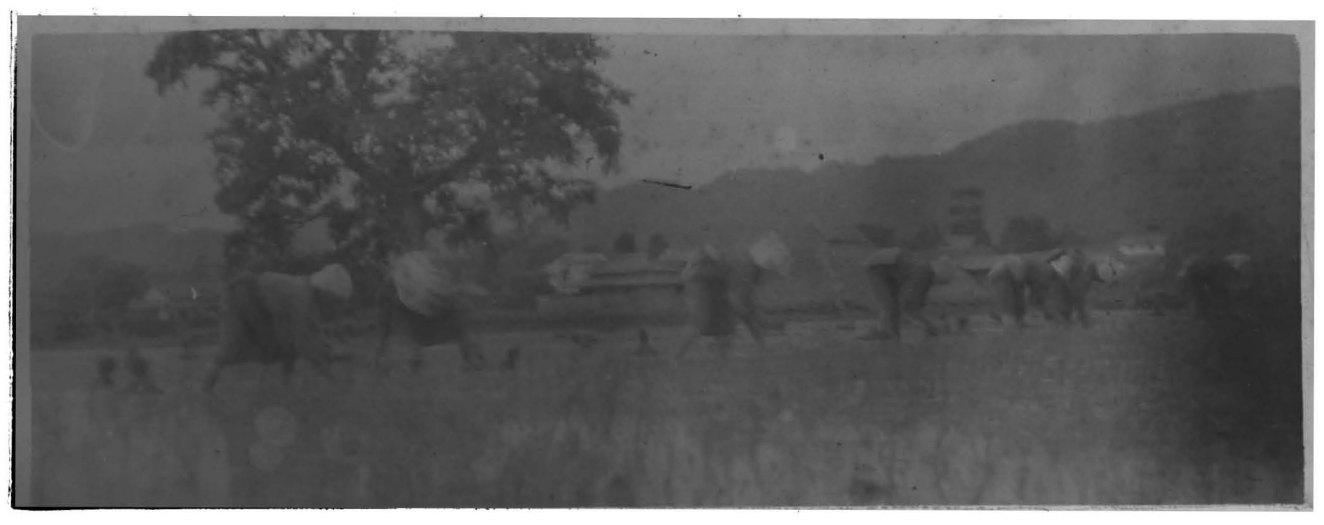

After about a week or ten days you may see the peasant, on hands and feet, going over his field, still under water, carefully clearing away with his hands any that may have started and loosening up the soil around the plants. This may be repeated once or twice and constitutes all that is necessary in the way of cultivation of the rice crop. The harvest comes in 0ctober usually and here the farmer is no better off than he was at planting time, for reap hook is his best machine, while for threshing etc. a kind of heckle, a flail, a large stone or wooden mortor with a kind of pestle, a small stone hand mill etc. constitute his implements.

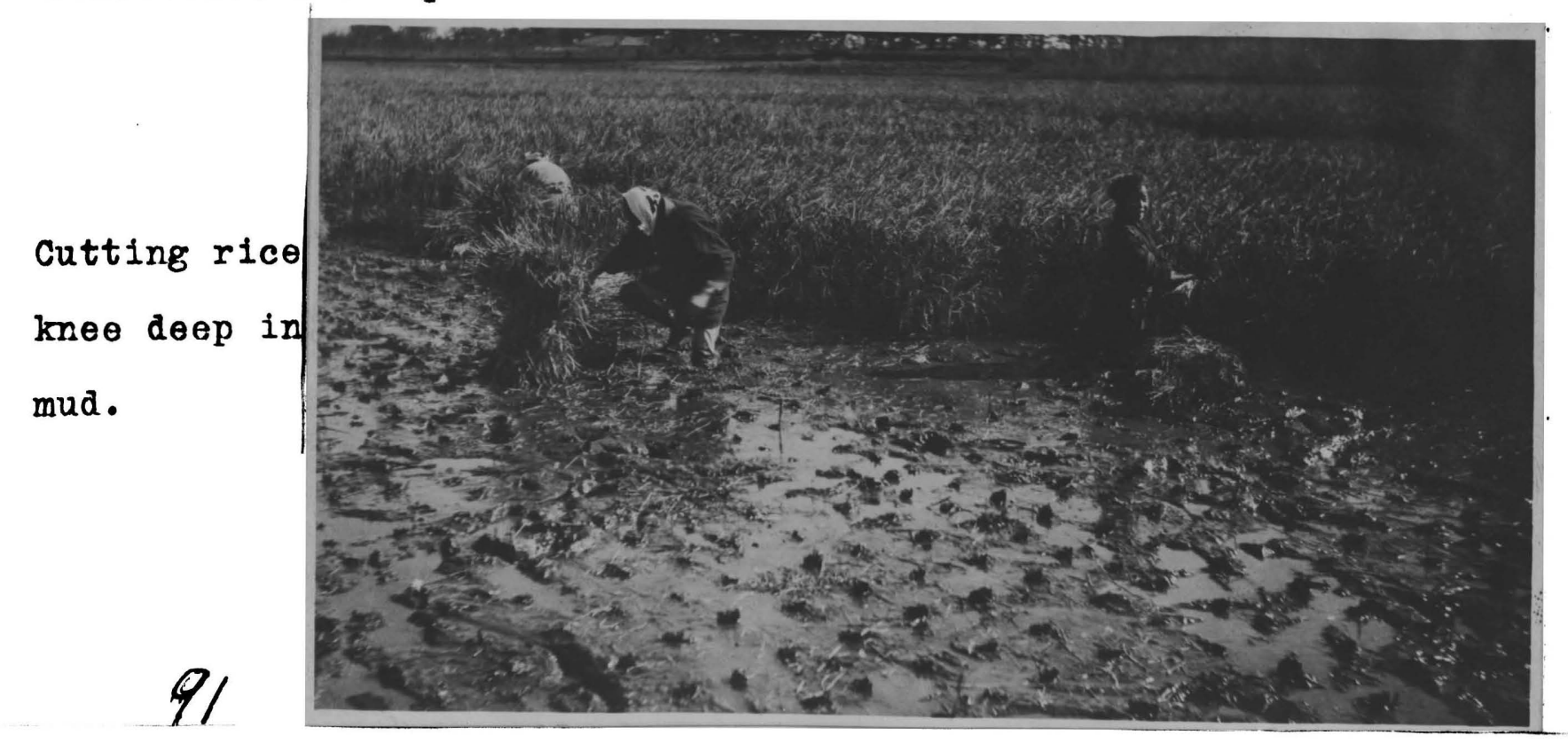





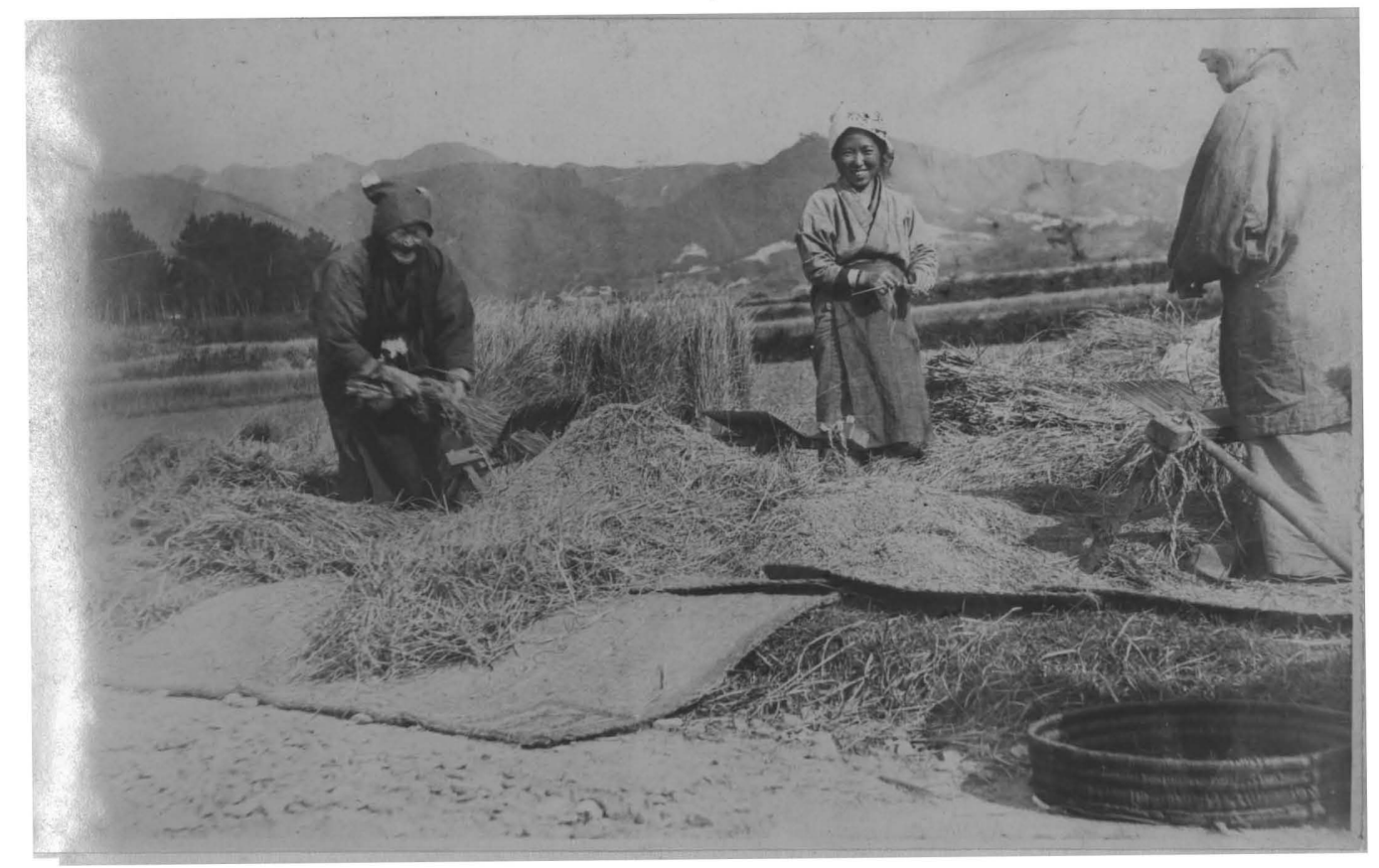

Separating the grain f'rom the straw. This is followed by the flail, to remove the hulls.

It has been estimated that the field tools of the average farmer if Jupan represents about $\$ 1.40$ in value. With other crops the methods are not far different except that the field is dry instead of flooded, and the crop is cultivated, even wheat and barley being sown in rows and cultivated.

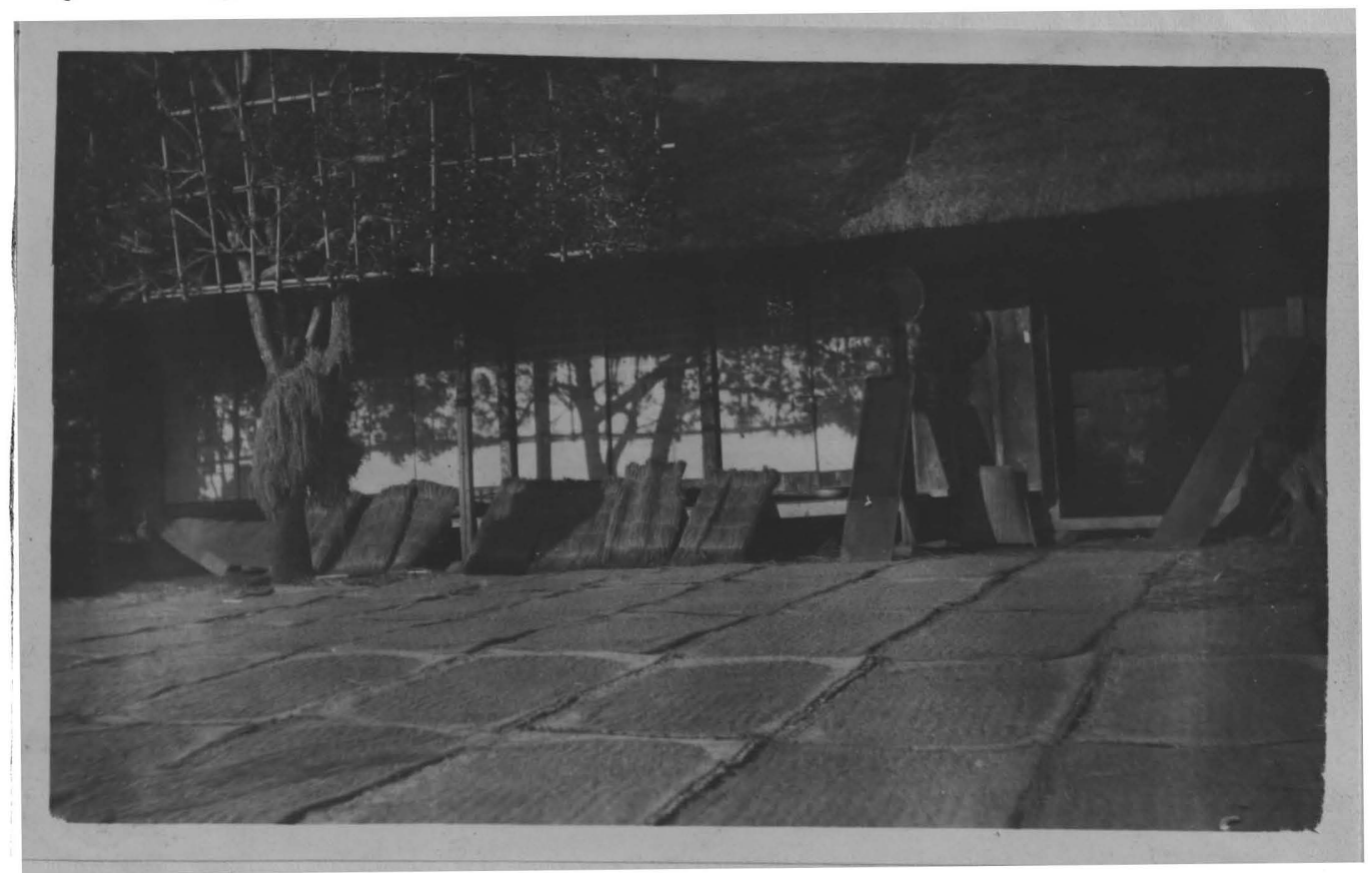

Drying grain on mats. 


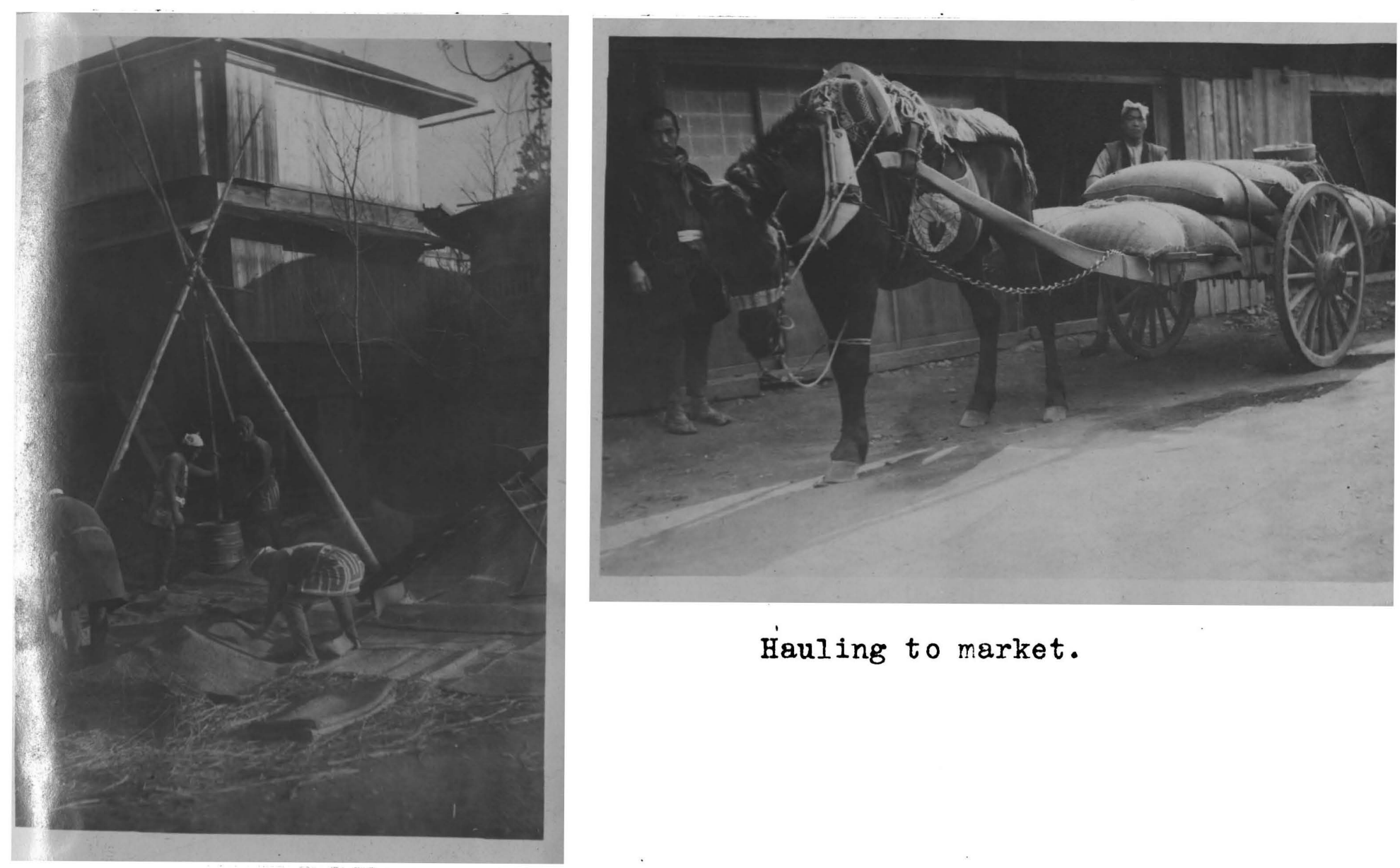

Hauling to market.

cleaningrain.

Since these primitive methods are in use one would naturaliy expect that each man could cultivate only a very small plot of land, as compared with our own broad fields. According to figures given in "Japan at the Beginning of the Twentieth Century", the average extent of land for one farming family is 2 I/2 acres. ${ }^{1}$ Murray, however, in his history of Japan, says"It has been estimated that the average amount of land under cultivation is only about three-fourths of an acre for each of those engaged in farming". 2 These two statements are not necessarily opposed since often there are two or more members of the same family engaged in farming. Mr. Simmons in in notes claims that from time immemorial about half an acre of

1. Japan at the Beginning of the 20th Century, p. 88

2. Japan, in History of the Nations Series, p. 18 

land has been regarded as sufficient for the support of one person. In the Iand Provision of the Toiko Code of laws of 70R A.D. the land granted to each individual as $\mathrm{Ku}$-bu den or "mouth share land" was for men .49 acre-for women .1632 acre.

This land is not usually all together but is separated Into two or even three plots and these are often some distance apart. It is not hard to see therefore that the ordinary field in Japan is about what we would call a garden spot, and in faot often much smaller, for tit usually contains not more than onefourth of an acre. Fleldsare of no certain shape nor all the same size, the recently there is a movement gaining favor for replotting the land and laying out the fields larger and uniform in shape. The Government must needs assiat in this rearrangement because it is expensive work, since all irrigation ditches must be remade, and then there is necessarily a great deal of trouble in securing to each man his proper amount of 1and. Each field is bordered by a low ridge which serves to keep the water in when flooding the field and at the same time forms the only boundary line betweon fields. These ridges are often utilized by being planted to beans.

In the order of their importance in the country the orops may probably be mentioned as follows;- rice, wheat, barley, rye, millet, beans, buckwheat and dalkon. The average yield of rice per acre for the nine fears from 1895 to 1903 was 27. 932 bushels. Of the other crops the following figures may be taken as fair estimates for the three year8-1882, 1887 and 1891;- wheat, sixteen bushess per acre, barley, twenty four

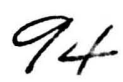



bushels, rye twenty bushels, beans fourteen, buckwheat thirteen bushels. I am not prepared however to give the value per bushel of these crops.

ership of Iand. Regarding the ownership of land and the proportion of land owners or independent farmers to tenants it is difficult to procure accurate data, It was only after the Restoration in 1868 that the right of ownership of land by private individuals was firmly established, and not till 1875 was it proclaimed that the title deed should bear the name of the owner. The only recent statistics regarding the number of independent farmers and tenants are those of 1888. According to these, in thirty-eight of the forty-six prefectures, there were twice as many farmers who were partly or wholly tenants as there were those who owned their own land. The number however who were wholly tenants was less than half this number who were partly so. So in point of fact there were more independent farmers than those who were wholly tenants. But as matters have been less favorable since then for the small free holder it is probable that now the number of tenant farmers must be greater. In former times, however, only a very serious matter would lead a landowner to dispose of his holding and at the same time it was only with difficulty that he was able to do so. In 1643 a law was passed prohibiting the sale of land, because, "If farmerssare permitted to sell their land, a ronin (an individual away from his native place and therefore an outcast), samurai. merchant, rioh farmer or other person might buy up a whole village or township and defy the Government." 1

1. Transactions of the Asiatio Society of Japan, XIX-pt. I p. 73 .

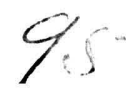



Iikewise, "The perpetuity of the family being the basis of the sooial fabric, the inheritance of the family received a peculiarly sacred character. The integrity of the inheritance received from the ancestors was preserved at all costs. INo one generation had a right to the exclusive use of it". "The ownership of the records of the genealogy, the articles used in house worship, and the family tombs constitutes the especial right of succession to the headship of the nouse". I The legal reatrietions on the sale of land have been largely removed and the moral obligation to keep intact the estate is overcome often by the stress of circumstances and hard times, so that there is slowly growing up a new form of country gentry, the large land owners,- tho perhaps in the majority of cases the large land owners obtained their holdings by reolaiming tracts of swamp land etc.

"To the peasant, tilling his littlo rico field year after year, have come the heavy burdens of taxation; the grinding toil for a mere pittance of food for himself and family; the patient bearing of all things imposed by his superiors, with 11ttle hope of gain for himself, whatever change of fortunes war may bring to those above him in the social scale".2

In short it would be practioally impossible for the peasants to live if they depended wholly upon the returns from the land. But almost all have other work with which to employ their iale hours. "In some cases the farmers divide their time and labor almost equally between this subsidiary work and their

1. Ancestor Worship, p. 70. Nobushige Nozumi.

2. Japanese Girls and Women, p. 229. 

regular farming work, being therefore partly farmers and partly manufacturers: of goods".1 We will have occasion to remember this last fact when we consider the manufacturing of the country for most of it is done in this way. This subsidiary work of the farmers may be given as follows;- 1. The manufacture of food stuffs, such as, starch, macaronl, rice cakes, bean curd, jam, dried persimmons, dried radish etc. 2. The manufacture of matting, straw braid, rope, rain coats, hats, charcoal bags, willow baskets and such like. 3. The weaving of fabrics, spinning of yarns, and manufacture of silk and paper. 4. Salt making, charcoal and lime burning, camphor refining etc.

Farm Labor. Farmers are usually their own laborers (this includes the women of the family for they labor almost as much in the field as the men). There are not many who make it their business to work out in agricultural work. Of those who do there are two classes, - day laborers and those who contract for the year. These latter usually live with their emplojers and receive their food and clothing, together with their wages, which according to the official statiatics for 1900 were for men on - an average $\$ 16.06$ and for women $\$ 8.53$ for the year. The same returns give the wages of day laborers on the farm, for men at fifteen cents and for women, ten cents per day. Lads are sometimes engaged for a term of five or seven jears who rarely receive more than their keep.

Regarding rent, we are able to say the following;- in the Shogunate domains in Tokugawa time generally five parts of

1. Japan at the Beginning of the Twentieth Century, p. 210

$$
97
$$



the produce of the land went to the Government and five parts to the farmer. In some of the daimiates six or seven parts went to the daimyo. In fact often the principle followed wasnTax up to such a point that just enough for subsistence remains". And yet- "The time of the annual payment of the rice at the collectors' storehouses where each farmer's rice was submitted to inspection, instead of being an occasion of sorrow and irritation, was more like a fair where each vied with the other in presenting for official inspection the best return of rice". 1 This is easily accounted for if the following is true"The payment of taxes did not seem to be regarded by the peasantry as a burden, but as a loyal duty, in which they too more or less pride". 2 At present it is the common thing. I understand, for the land owner to take one-half of the produce of the land or sometimes this arrangement is made-that he takes one-half of the first crop, the tenant being allowed a larger share, sometimes even all of the second crop. The Year Book for 1905 differs with my estimates however by saying;- "The share which Iand ownereand tenant farmers take out of the produce of the farm 18, roughly stated, six parts for the former and four for the latter in regard to paddy fields, while the relative ratio is $41 / 2$ and $51 / 2$ respectively for upland farms". 3

1. Transactions of the Asiatic Socioty of Japan, V61. SXIX pt I

3. Japan Year Book, 1905 p. 102. 

IVING EXPENSES.

Just a word here as to the cost of living in Japan will perhaps be in order. This cost is decidedly less than it is in America. This is due to many things, the cheapness of. labor, the simple quality of the food and household arrangements etc. The following data taken from"The Labor World" for July I, 1898 gives some concrete examples of the expenses of families. This gives the budgets of laborer's families of which the two following are samples:- No. 1-House, two rooms; a family,-man (30), wife (23), mother (53), two sisters (14 and 11); occupation, blacksmith.

Working deys in a month

Working hours in a day

Daily wages $\$ .52$

Monthly income 13.82

Monthly expense 13.65

House rent per month .96

Rice

5.76

Fuel and light

1.08

Vegetables .87

Fish .96

Sake (rice beer) .24

Soy (Japanese sauce) .73

Tobacco .20

Hair cutting and dressing .83

Bath .88

Pin money .25

Sundries .89

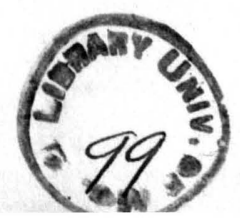



No. 55. House, two rooms with kitchen; a family-, man (27), wife (25), boy (6), girl (2); busines, iron worker.

$\begin{array}{lc}\text { Daily Wages } & \$ .25 \\ \text { Over time income per month } & 1.50 \\ \text { Monthly income } & 8.28 \\ \text { Monthly expense } & 9.44 \\ \text { House rent } & .75 \\ \text { Rice } & 3.25 \\ \text { Fuel and light } & .41 \\ \text { Vegetables } & .60 \\ \text { Fish } & .60 \\ \text { Soy and miso } & .23 \\ \text { Tobacco } & .25 \\ \text { Hair cutting and dressing } & .18 \\ \text { Bath } & .20 \\ \text { Pin money } & .60 \\ \text { Sundries, including interest } & \\ \text { on debt } & \end{array}$



ISHING.

We shall not be far wrong if we take fishing as the industry of next importance in Japan. A Japanese publication 6ays- "Fish and other marine products have constituted from olden times, the most important artiole of food uied by our people". Owing to the geographical position, to the direction of marine currents, to the proximity to the sea of so many of the people and also to the abundance of suitable indentations along the long coast Iine, Japan is an ideal country for the fisherman. It is not surprising therefore that the poople eat daily a largo amount of flsh and that there are 900,000 families engaged in fishing. There are in use likewise about 420,000 fishing boats. These boats are nearly all less than thirty feet in length and propelled by soulls $\%$

About the only data available concerning the value of the boats, nets etc. used by fishermen are those for the year 1891. According to these returns we find the total investment is about $\$ 12,000,000$ which represents an investment of $\$ 13.331 / 3$ per family. There are other fighing gear besides boats and nets, but of comparatively small value.

The average value of the takes from the sea per year Is $\$ 23,699,586.00$, of other marine products $\$ 14,499,023.00$. This, 1f we again take an average for the 900,000 famtlies engaged in fiahing, gives about $\$ 42.50$ per family per jear. Of the takes herring and salmon stand first, tho about forty or fifty other kindsare taken in sufficient quantities to count for considerable value.

1. Japan at the Beginning of the 20th Century, p. 231

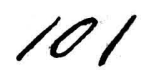





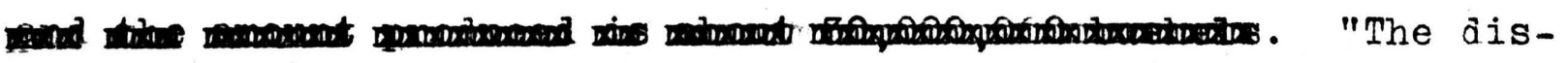
tricts bordering on the Inland sea produce about eight-tenths of the whole out put in Japan proper". There are two methods of refining, by natural and by artificial heat, or rather a combination of natural and artificial heat, since in the first part of the process the evaporation is by the sun's heat only, but in the second part, when the concentration has reached a high state, it is subjected to artificial heat. That by natural heat does not differ greatly from the same process as carried on in other countries.

There may be said to be two methods in use in refining by artificial heat, the difference being in the first part of the process. According to the method most in use the sea water is let into the enclosure at high tide and allowed to stand until it "has evaporated to such an extent as to cause it to derosit the saline matter it contains; the deposits are (then) collected and transferred to a box-shaped vessel made of either mud or wood." Sea water is now poured into the ressel and the thick liquid thus obtained is carried to large reservoirs at the side of the salt field. The only difference in the other method is that instead of the water being admitted so as to cover all the enclosure constituting the field, it is confined to ditches running along the sides- or all thru the field and from these the water is repeatedly sprinkled over the ground-the remainder of the process being the same. The brine is draw from the reservoirs and put into large vats often made of stone- under which the heat 

is placed and soon there remains only a quantity of crude salt. The production of salt from sea water has probably been carried on in Japan no less than twenty centuries. There are now more that 100,00 o peple engaged in this work, and the average annual production is about $30,000,000$ bushels of salt. It is carried on in about thirty-four of the forty-six prefectures.

TEA.

There are two other induatries very closely allied to agriculture- in that the farmer often carries on one or both. These are Tea Reising and Sericulture, or the rearing of the silk worm.

It is thought that tea was introduced into Japan from China about 800 A.D., but little or no progress was made in the culture till the twelfth century. About this time tea drinking became fashionable in the court and among the aristocracy, and the tea ceremony, Che no It is doubtful tho if the custom of tea arinking became at all general among the common people before the beginning of the eighteenth century. At present the tea house, where one may always find tea, cakes and a few sweet meate etc. for sale, is one of the most widely spread, socially most important, and to wayfarers most agreeable of Japanese institutions". 1 At the same time tea is universally arunk in the homes, at meal time and as a beverage between meals. No guest is allowed to depart

1. Things Japanese, p. 453.

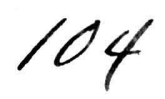



even from a five minute call, without being served tea and cakes. The cups however are very small and the quantity of tea is often not more than two teaspoonfulls at a tire, tho the host will continue to replenish the cup as often as the guest empties it. It must be remembered too that this is straight tea- no milk and sugar. To many Western people the taste of Japanese tea is far from agreeable. It is not a breach of etiquette, some may be glad to know, to refrain from drinking, or to request only hot water instead of tea. In the houses, in the shops, in the schools, in the field-everywhere one finds tea.

As a rule the tea plants are found on the sloping mountains or hill sides- sometimes in the valleys, both in large plantations and in the spare places about homes- to the extent of about 222,000 acres. They are allowed to attain a height of three or four feet. The picking is done largely by women- and with their large straw hats or towels on their heads-dotting the fields they make a picturesque sight. The first picking takes place at the end of April or the beginning of liay and lasts three or four weeks. There is then a second picking in June or JulJ, and sometimes a third. At Uji, the most famous place for tea in in Japan, temporary roofs are constructed over the tea gardens about thirty days before picking time in order to protect them from chilling dews. "As soon as possible after being picked, the leaves are placed in a round wooden tray with a brass wire bottom over boiling water. This process of steaming, which is complete is half a minute, brings the natural oil to the surface.

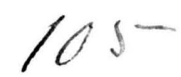



The next and principle operation is the firing, which is done in a wooden frame with tough Japanese paper stretched across it, charcoel well covered with ash being the fuel employed. This first firing is done at a temperature of about $120^{\circ} \mathrm{F}$. Meanwhile the leaf is manipulated for hours by men who roll it into balls with the palms of their hands. The final result is that each leaf becomes separately twisted, and changes its color to dark olive purple. Two more firings at low temperatures ensue, after which the leaf is allowed to dry until it becomes quite brittle. Sometimes- and we believe this to have been tre common practice in anclent days- the leaf is not fired at all, but only sun aried!l.

The cost of the tea used in ordinary household is usually about ten or fifteen cents a pound, tho among the lower classes there is the so-called bancha, made out of chopped leaves, stalks and bits of wood from trimmings of the tea plant, and this sells for about five cents a pound. Some qualities of tea however sell as high as five and ten dollars a pound.

To make Japanese tea properly water several degrees below boiling is used, since boiling water brings out a very bitter taste, and this water is allowed to stand on the tea for only a very short time.

No disquisition on Japanese tea is complete without something being said about the truly famous tea ceremonies- but as these belong more to the aristocracy than to the common people a desoription of them would be out of harmony with this paper.

1. Things J spanese, p. 454 . 

We cannot refrain, however, fron making the following remark.

To the Japanese mind, to be in the company of a few kindred souls, to spend the long hours of a summer's afternoon at a tea party. olpping tea and conversing in leisurely manner on various subjects is an enjoyment second to none.

\section{SHRICULTURE.}

The rearing of silk worms dates from the foundation of the Japanese Impire, tho no marked progress was made till the second or third century of the Christian era. But long before the jear 1000 A.D. we find that silk raising and weaving had come to occupy the principle place among the productive industries of the country. Silk had come to be accepted for tributes and contributions to the Imperial Government, while $811 \mathrm{k}$ fabrics had also come to be used in general for wearing purposes". I Today there are few places through-out the country where one will not find the mulberry trees and the accompanying culture of silk works, tho for observing the latter one must seek admission to the homes, for only there is the work carried on, and during the rearing season the house and the people living in it are almost wholly given over to this one business. The whole house will be filled with worms, especially at the time of forming the coooon, and the people tend them day and night with a great deal more care than they do their own offepring. In 1901 the number of families engaged in sericulture was $2,475,819$, and these produoed about 12,600,000 bushels of coooons. These in turn pro-

1. Japan at the Beginning of the 20th Century, p. 164.

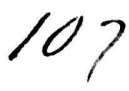



duced about $14,000,000$ pounds of raw silk.

The United States is the best customer of Japanese raw silk, taking between fifty and sixty per cent of the whole amount exported.

There is found, on some parts of Japan, a kind of silk worm that feeds on oak leaves, instead of mulberry, and it produces silk of a delicate green shade which is valued more than ordinary silk.

\section{INUFA CTURIITG.}

Japan has never been and is not to-day a manufacturing

nation in the sense in which we use that term among western nations. She has few large factories, and what few there are have been introduced within the past fow years. There is a sense however in which we must consider the manufacturing industry of the country.

As was mentioned under the head of Secondary Industries of the Farmers, a large proportion of the commercial goods of Japan are made on a small scale in the homes of the common people. (The following are some of the things that were prepared for market in this way before the opening of the country to foreign commerce, and many of them are even now very largely so made:- raw silk, 'silk fabrics, hemp fabrics, cotton fabrics, porcelain, laquered ware, copper ware, Japanese paper, matting, sake, and soy, iron ware and cutlery, wood, bamboo, and leathern ware $)^{1}$

When foreign merchants came and began to buy these things they tried of course to put into practice European customs,

1. A recent article (4/11-09) in the Kansas City Journal by Frank G. Carpenter, on "Cotton Factories" in Japan gives a very good idea of manufacturing as it is carried on in the modern sense 

expeoting all articles to conform to the sample shown and to be uniform. But when the goods were brought together, it may be from 100 or 200 or more different families where they were made, they werie not, and could hardly have been expected to be, all alike. The foreign merchant therefore objected that the Japanese trader had not lived up to his contract and perhaps refuged to accept the goods. The Japanese, on the other hand, perhaps unaware that there wa any method of making a large number of articles all exactly the same and in a short time in large factories, regarded the merchant as a very unreasonable man and one on whose word no dependence was to be placed. Thus it was in the early intercourse between Japanese traders and foreign traders that misunderstandings arose and each thought the other unprincipled- while the truth is both were acting on their training and each was honest according to his understanding.

IONEY AND OTHER WEIGH TS AND NEASURES.

The present day monetary system in Japan is very little different from our own. The money consigts of gold, silver, copper and paper money. The yen, equal to about fifty cents, is the standard. Gold is coined in 1,2, 5, 10, ind 20 yen pleces, tho gold is not at all in common circulation, especially in the country districts, in fact I do n ot remember having seen any gold coine during my stay in the country. Silver circulates in 5, 10,20 and 50 sen and 1 yen pieces, tho the one yen are very rare. In copper there are 1 and 5 rin, 1 and 2 sen pieces. In oitieg the rin, which is equal to one-tenth of a sen, is not 

in circulation very much, but in the small villages it is still used a great deal. Paper money is in 1, 2, 5, and 10 yen bills. The measure of length is the shaku which equals 11.93 inches. But in cloth measure a shaku is used which is equal to 14. 91 inches. In measuring distance the $\underline{r i}$ is the standard and It is common to call it $21 / 2$ miles $(2.4403$ t. Thirty-six cho make one $\underline{\text { i. }}$. The kin is the measure of weight and it is equal to 1.325 pounds avoirdupois. One hundred and sixty momme make one $\underline{\mathrm{kin}}$ and $6 \mathrm{l} / 4 \mathrm{kin}$ equals a kwan. In measures of capacity 10 go (equal to .0199 peck) make one sho and 10 sho, one to and 10 to one koku or 4.96 bushels. In superficial measure the standard most commonly used is the tsubo which is, roughly speaking, thirty six square feet $(39.53)$. This is the standard for measuring land. 

VIILAGE IIFE IN JAPAN.

IBIIOGRAPHY.

1. Things Japanese -... B. H. Cnamberlain.

2. Japan- An Interpretation -... Iafcadio Hearn.

3. Glimpses of Unfamiliar Japan -... Lafcadio Hearn.

4. A Handbook of Modern Japan ...- E. W. Clement.

5. Christianity of Modern Japan -... E. W. Clement.

6. The Religions of Japan .... W. E. Griffis.

7. The Mikado's Empire -..- W. F. Griffis.

8. The Heart of Japan -... C. I. Brownell.

9. Iooal Finances in Japan .... Bunshiro Hattori.

10. Japan as it was and is .... R. Hildreth. Edited by K. Murakawa.

11. Japan Year Book-- 1905 .

12. Japan at the Beginning of the Trentieth Century. Compiled H. Yamawaki for the Osaka Exposition, 1903.

13. Transactions of the Asiatic Society of Japan, especially volumns XIX, pt. I and XXXIII, pt. II.

14. Japanese Girls and Women -... Alice M. Bacon.

15. Unbeaten Tracks in Japan -... Miss Bird.

16. Ancestor Worship -.. Nobushige Nozumi.

17. Japan, in History of the Nations Series -... Murray.

13. Japanese Homes and Their Surroundings -... E. S. Morse.

19. The Japanese Bride -... Naomi Tamura.

20. Bushido- The Soul of Japan -... Dr. Nitobe.

21. Religions of Mission Fields as viewed by Protestant Missionaries 

22. Thirty-first Annual Report of the Minister of State for Education for the year 1903-4.

23. The Evolution of the Japanese -..- Sidney I. Gulick.

24. Japanese Buddhism

25. Industries of Japan .... J. J. Rein.

$1 / 2$ 




